\title{
Geochemical and microbiological fingerprinting of airborne dust that fell in Canberra, Australia, in October 2002
}

\section{Patrick De Deckker}

Research School of Earth Sciences, Australian National University, Canberra, ACT 0200, Australia

(patrick.dedeckker@anu.edu.au)

Raeid M. M. Abed

Max Planck Institute for Marine Microbiology, Celsiusstraße 1, D-28359 Bremen, Germany

Biology Department, College of Science, Sultan Qaboos University, P.O. Box 36, Postcode 123, Al Khoud, Sultanate of Oman

\section{Dirk de Beer}

Max Planck Institute for Marine Microbiology, Celsiusstraße 1, D-28359 Bremen, Germany

\section{Kai-Uwe Hinrichs}

Department of Geosciences and Center for Marine Environmental Sciences, University of Bremen, D-28334 Bremen, Germany

\section{Tadhg O'Loingsigh}

School of Geography and Environmental Science, Monash University, Clayton, Victoria 3800, Australia

\section{Enno Schefuß and Jan-Berend W. Stuut}

Center for Marine Environmental Sciences, University of Bremen, D-28334 Bremen, Germany

\section{Nigel J. Tapper}

School of Geography and Environmental Science, Monash University, Clayton, Victoria 3800, Australia

\section{Sander van der Kaars}

Department of Palynology and Climate Dynamics, Albrecht von Haller Institute for Plant Sciences, University of Göttingen, Untere Karspüle 2, D-37073 Göttingen, Germany

[1] During the night of 22-23 October 2002, a large amount of airborne dust fell with rain over Canberra, located some $200 \mathrm{~km}$ from Australia's east coast, and at an average altitude of $650 \mathrm{~m}$. It is estimated that during that night about $6 \mathrm{~g} \mathrm{~m}^{-2}$ of aeolian dust fell. We have conducted a vast number of analyses to "fingerprint" some of the dust and used the following techniques: grain size analysis; scanning electron microscope imagery; major, trace, and rare earth elemental, plus $\mathrm{Sr}$ and $\mathrm{Nd}$ isotopic analyses; organic compound analyses with respective compound-specific isotope analyses; pollen extraction to identify the vegetation sources; and molecular cloning of $16 \mathrm{~S}$ rRNA genes in order to identify dust bacterial composition. DNA analyses show that most obtained 16S rRNA sequences belong mainly to three groups: Proteobacteria (25\%), Bacteriodetes (23\%), and gram-positive bacteria (23\%). In addition, we investigated the meteorological conditions that led to the dust mobilization and transport using model and satellite data. Grain sizes of the mineral dust show a bimodal distribution typical of proximal dust, rather than what is found over oceans, and the bimodal aspect of size distribution confirms wet deposition 
by rain droplets. The inorganic geochemistry points to a source along/near the Darling River in NW New South Wales, a region that is characteristically semiarid, and both the organic chemistry and palynoflora of the dust confirm the location of this source area. Meteorological reconstructions of the event again clearly identify the area near Bourke-Cobar as being the source of the dust. This study paves the way for determining the export of Australian airborne dust both in the oceans and other continents.

Components: 11,338 words, 16 figures, 1 table.

Keywords: aeolian dust; biogeochemistry; polymerase chain reaction; 16SrRNA cloning; trace element geochemistry.

Index Terms: 1029 Geochemistry: Composition of aerosols and dust particles; 1065 Geochemistry: Major and trace element geochemistry; 1055 Geochemistry: Organic and biogenic geochemistry; 0488 Biogeosciences: Sulfur cycling; 3322 Atmospheric Processes: Land/atmosphere interactions (1218, 1631, 1843).

Received 10 May 2008; Revised 18 September 2008; Accepted 30 October 2008; Published 24 December 2008.

De Deckker, P., R. M. M. Abed, D. de Beer, K.-U. Hinrichs, T. O’Loingsigh, E. Schefuß, J.-B. W. Stuut, N. J. Tapper, and S. van der Kaars (2008), Geochemical and microbiological fingerprinting of airborne dust that fell in Canberra, Australia, in October 2002, Geochem. Geophys. Geosyst., 9, Q12Q10, doi:10.1029/2008GC002091.

Theme: Eolian Dust as a Player and Recorder of Environmental Change

Guest Editors: M. Prins, D-D. Rousseau, and J-B. Stuut

\section{Introduction}

[2] The contribution of dust plumes from Africa to the Atlantic Ocean, the Caribbean, and the Amazon Basin is now well documented [Duce et al., 1980; Savoie and Prospero, 1980; Talbot et al., 1988; Swap et al., 1992; Prospero, 1999; Stuut et al., 2005], especially since the availability of satellite imagery. Estimates of the amount of dust transported from Africa identify that huge amounts of sediment are deflated from African soils and lake basins. Griffin [2007] recently reviewed our knowledge of the microbial content (bacteria, fungi, and viruses) of airborne dust from many parts of the world that raise concerns not only for human health but also the "health" of the environment, including coral reefs with several bleachings of corals registered after African dust reached the western shores of the Atlantic Ocean [Shinn et al., 2000]. In addition, high concentrations of particular metals can occur in airborne dust, such as mercury found in Florida, are now considered to have originated from African dust [Landing et al., 1995; Holmes and Miller, 2004]. All these phenomena associated with aeolian dust deserve much consideration in Australia as too few investigations have been carried out on dust composition, especially with respect to its organic composition and microbiology, plus metals. Nevertheless, there are already several published accounts on the sedimentological characteristics and inorganic chemistry of several dust deposits [McTainsh, 1989; Hesse, 1994; Hesse and McTainsh, 2003; Marx et al., 2005; Petherick et al., 2008]. It is noteworthy that many Australian dust plumes originate from (hyper)saline lake floors, i.e., organic, metal, and microbial contents pertinent to saline conditions [De Deckker, 1988] and it is at the source of dust that investigations need to be carried out, and it is our intention to eventually investigate the effects of Australian dust on oceanic life, including corals and the seafloor microbiology. The study presented herewith is the first attempt at using as many techniques as possible to "fingerprint" a sample of airborne dust, much of which became available after a spectacular dust fall associated with some rain in October 2002 in Canberra, the capital city of Australia [McTainsh et al., 2005].

\section{Canberra Dust Event of 22-23 October 2002}

[3] The year 2002 proved to be a year of extensive drought in Australia and, in particular, for the vast $\sim 1.10^{6} \mathrm{~km}^{2}$ Murray Darling Basin, due to a significant rainfall deficiency combined with above maximum temperatures that led to a reduction in vegetation cover [McTainsh et al., 2005]. It is no surprise therefore that on 22 October that year a frontal system accompanied by vast 


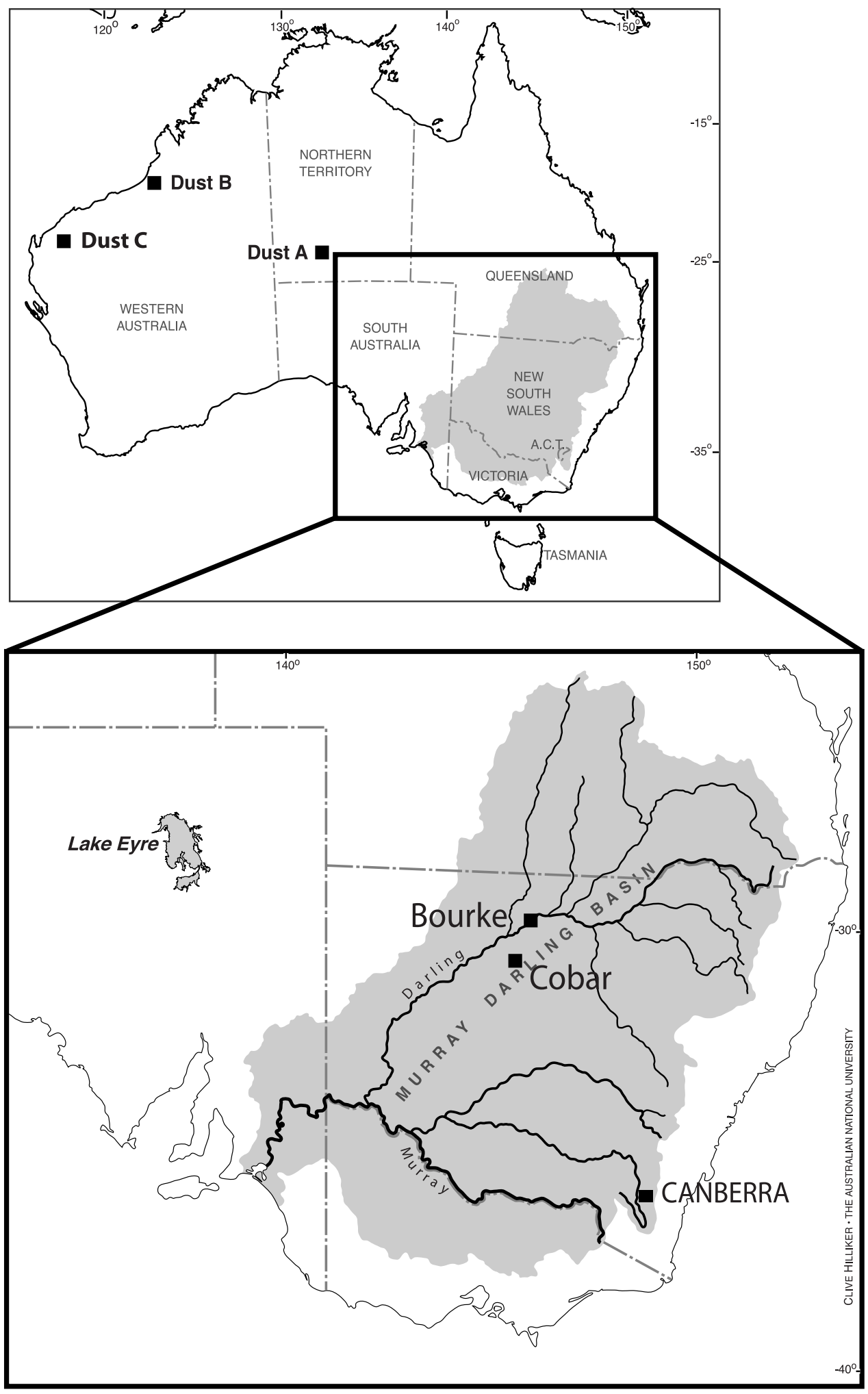

Figure 1. Maps showing the location of the Murray Darling Basin in Australia and all the major tributaries of the two major rivers Darling and Murray. The location of three dust samples from central and northwestern Australia that are compared against the dust sample originating from Canberra discussed in this paper are also shown. 
quantities of dust moved through South Australia and, over the following $36 \mathrm{~h}$, it transgressed eastern Australia [McTainsh et al., 2005]. The dust associated with this front spanned over $2400 \mathrm{~km}$ from Mackay $\left[21^{\circ} 09^{\prime} \mathrm{S} 149^{\circ} 11^{\prime} \mathrm{E}\right]$ in Queensland in the north down to the VictorianNew South Wales border $\left[37^{\circ} 30^{\prime} \mathrm{S}, 150^{\circ} \mathrm{S}\right]$ in the south (Figure 1). The front eventually continued over the Tasman Sea where a dust plume was tracked by satellite images on 24 October 2002 [see Chan et al., 2005, p. 340] that also clearly show dust over the southern part of the Great Barrier Reef.

[4] McTainsh et al. [2005] described the meteorological data for this spectacular event and concluded that the "dust storm was $2,400 \mathrm{~km}$ long, up to $400 \mathrm{~km}$ wide and 1.5 to $2.5 \mathrm{~km}$ in height." These authors also estimated that the dust load was 3.35-4.84 Mt and concluded by saying that this event represented the largest dust storm reported for Australia. During the night of 22-23 October 2002, it rained in Canberra which was located under the path of the dust plume. The rain that fell yielded a large amount of brown mud that covered many surfaces in the Canberra area. Atmospheric conditions that led to the entrainment of dust, and its transport via the atmospheric front in eastern Australia are discussed by McTainsh et al. [2005] and Chan et al. [2005] but are further developed here, especially with its precipitation and deposition in the Canberra region.

[5] Canberra is located at an average altitude of $650 \mathrm{~m}$ on the eastern edge of the Murray Darling Basin (which is drained by two of the Australian major rivers, the River Murray and the Darling River) (Figure 1). The latter river drains a large portion of the northern and western parts of the basin which is characterized by being semiarid to arid and with rains principally falling in the summer.

[6] This paper aims to identify the nature of the dust that fell in Canberra, to "fingerprint" it chemically with respect to its inorganic and organic components. In addition, DNA was extracted using polymerase chain reaction (PCR) from a subsample of the dust, and its palynoflora was also studied. A combination of the latter three approaches has never been undertaken before anywhere in the world for a sample of airborne dust. The overall aim was to identify the source of the dust and to determine characteristics of airborne dust that may one day be used to identify aeolian components in lacustrine and deep-sea cores in the Australian region and elsewhere.

\section{Material and Methods}

\subsection{Collecting the Dust}

[7] By chance, one of us (PDD) cleaned a series of almost horizontal windows the weekend prior to the Canberra dust fall that occurred on the night of 22-23 October 2002. These windows are next to a house in the heavily treed suburb of Aranda which is located near the center of the city, away from any industrial area, north of the forested Black Mountain Reserve. The morning after the event, a thick, dried paste of brown mud covered the windows and the material was carefully sampled using clean, unused razor blades. This material was transferred into clean glass scintillation vials, then sealed and subsequently stored at $4^{\circ} \mathrm{C}$.

[8] Several subsamples of the dust material were selected for a variety of analyses, including one that was sent to the Max Planck Institute of Marine Microbiology some 2 years after its collection. Detailed chemical analyses of another subsample, including major and trace elements and rare earths, together with the organic compounds were performed. Additional work on other subsamples included observation of the material by scanning electron microscopy, grain size analysis, and pollen extraction and is also reported in this paper.

[9] By weighing another subsample, it is estimated that $6 \mathrm{~g} \mathrm{~m}^{-2}$ of dry weight fell (rained) on the windows of the Aranda home.

\subsection{Extraction of the Organic Compounds From the Dust Sample}

[10] A subsample of the Canberra dust has been extracted with a mixture of methanol, dichloromethane, and phosphate buffer at pH 7.4 (2:1:0.8; $\mathrm{v} / \mathrm{v})$ [Sturt et al., 2004]. After sonication for 5$10 \mathrm{~min}$, further dichloromethane and buffer were added to the mixture to achieve a final methanol/ dichloromethane/buffer ratio of 1:1:0.8. The phases were separated and the extraction repeated three more times. The total lipid extract (TLE) was reacted with BSTFA in pyridine to obtain trimethylsilyl (TMS) derivatives. The derivatized TLE was analyzed on a Thermoquest Trace GC-MS (Supelco SLB-5 ms column, $1 \mathrm{ml} / \mathrm{min}$ constant $\mathrm{He}$ carrier gas flow, temperature program: $60^{\circ} \mathrm{C}-$ 
$10^{\circ} \mathrm{C} / \mathrm{min}-150^{\circ} \mathrm{C}-4^{\circ} \mathrm{C} / \min -320^{\circ} \mathrm{C}$ with $40 \mathrm{~min}$ holding time). Compound identification is based on published mass spectra and retention times. Compound-specific stable carbon isotope $\left(\delta^{13} \mathrm{C}\right)$ analyses were conducted on a Finnigan MAT 252 GC-irm-MS at the University of Bremen, using the same capillary column and GC conditions as described above. Reported $\delta^{13} \mathrm{C}$ values were corrected for the introduction of additional $\mathrm{C}$ during the preparation of TMS derivatives.

\subsection{Molecular Analysis of the Dust Sample}

[11] The microbial communities within the dust sample were investigated by cloning of $16 \mathrm{~S}$ rRNA genes. DNA was extracted from the dust subsample $(\sim 300-500 \mathrm{mg})$ following the procedure established by Abed and Garcia-Pichel [2001]. For cloning, the 16S rRNA genes were amplified by PCR using the universal primers GM3F and GM4R [Muyzer et al., 1995]. The amplification was performed at an annealing temperature of $42^{\circ} \mathrm{C}$. The PCR products were purified using the QIA quick PCR purification kit (Qiagen, Hilden, Germany) and were cloned using the TOPO TA Cloning Kit (Invitrogen, Karlsruhe, Germany) according to the manufacturer's instructions. The obtained clones were screened for the presence of inserts and the positive clones were then sequenced.

[12] The obtained sequences of the clones were analyzed and compared using the ARB program [Ludwig et al., 1998]. The alignment was corrected manually. Phylogenetic trees were calculated by maximum parsimony based on long 16S rRNA sequences (more than $1300 \mathrm{bp}$ ). The obtained sequences were then inserted into the reconstructed tree by applying parsimony criteria, without allowing changes in the overall topology.

[13] For determining the number of operational taxonomic units (OTUs), similarity matrices among the sequences were calculated with the ARB program. One OTU was defined for sequences which have more than $97 \%$ similarity. Rarefaction curves were calculated using the freeware program aRarefactWin (available at http://www. uga.edu/ strata/software/Software.html). The coverage of the clone libraries, species richness, species evenness, and Shannon-Weaver index of diversity were calculated as previously described by Good [1953], Atlas and Bartha [1998], and Singleton et al. [2001].

\subsection{Pollen Extraction From the Dust}

[14] The sample was prepared in the palynological laboratory at Monash University and was initially treated with warm $10 \%$ Na-pyrophosphate $\left(\mathrm{Na}_{4} \mathrm{P}_{2} \mathrm{O}_{7}\right)$ and sieved over a 210 and a $7 \mu \mathrm{m}$ mesh. Organic material retained in the $7 \mu \mathrm{m}$ mesh was isolated from the remaining inorganic fraction using heavy liquid separation with sodium polytungstate $\left(\mathrm{Na}_{4} 6\left[\mathrm{H}_{2} \mathrm{~W}_{12} \mathrm{O}_{4} 0\right]\right.$. $\mathrm{H}_{2} \mathrm{O}$; s.g. 2.0, 20 min at $2000 \mathrm{rpm})$. The isolated material was then treated with acetolysis $\left(9\right.$ parts $\left(\mathrm{CH}_{3} \mathrm{CO}\right)_{2} \mathrm{O}: 1$ part $\left.\mathrm{H}_{2} \mathrm{SO}_{4}, 10 \mathrm{~min}\right)$. The remaining residues were dehydrated with ethanol $\left(\mathrm{C}_{2} \mathrm{H}_{5} \mathrm{OH}\right)$. Slides were mounted with glycerol $\left(\mathrm{C}_{3} \mathrm{H}_{5}(\mathrm{OH})_{3}\right)$ and sealed with paraffin.

\subsection{Grain Size Analysis of the Dust Sample}

[15] Grain sizes of the minimally dispersed dust were measured with a Coulter laser particle sizer (LS200) at the Research Center Ocean Margins, Bremen, Germany, resulting in particle-size distributions from 0.04 to $2000 \mu \mathrm{m}$. Particle sizes are presented as percentage volume per size class for 92 classes.

\subsection{Observations of Grain Particles of the Dust Under the SEM}

[16] A small amount of dust material was transferred onto nonconductive double-sided sticky tape, then coated with $\mathrm{Au}-\mathrm{Pd}$ in a small Ar chamber, and then observed under a Cambridge scanning electron microscope (SEM) at the Electron Microscope Unit at the Research School of Biological Sciences at ANU.

\subsection{Inorganic Geochemical Analyses of the Dust}

[17] Major elements $\mathrm{Na}, \mathrm{Mg}, \mathrm{Al}, \mathrm{Si}, \mathrm{P}, \mathrm{S}, \mathrm{K}, \mathrm{Ca}, \mathrm{Ti}$, $\mathrm{Mn}, \mathrm{Fe}$ were determined by XRF on a Philipps (PANalytical) PW2400 X-ray spectrometer in the former DEMS (now RSES) at ANU. Lithium borate discs were prepared by fusion of $0.27 \mathrm{~g}$ of dried sample powder and $1.72 \mathrm{~g}$ of " $12-22$ " eutectic lithium metaborate-lithium tetraborate. The major elements were calibrated against 28 international standard rock powders. Lithium borate discs were then dissolved in $2 \% \mathrm{HNO}_{3}$ and, after dilution, concentrations of the trace element Sc, V, Y, Cr, Mn, Co, Ni, Cu, Zn, Ga, Rb, Sr, Y, Zr, $\mathrm{Nb}, \mathrm{Mo}, \mathrm{Cd}, \mathrm{Sn}, \mathrm{Cs}, \mathrm{Ba}, \mathrm{La}, \mathrm{Ce}, \mathrm{Pr}, \mathrm{Nd}, \mathrm{Sm}, \mathrm{Gd}$, $\mathrm{Dy}, \mathrm{Er}, \mathrm{Yb}, \mathrm{Lu}, \mathrm{Hf},{ }^{207} \mathrm{~Pb},{ }^{208} \mathrm{~Pb}$, Th, and U were measured by ICP-MS at RSES at ANU. The 
samples were calibrated against NIST 612 blue glass as an external standard material, using $\mathrm{CaO}$ or $\mathrm{SiO}_{2}$ as an internal standard component. The external standard was reanalyzed every $10-15$ samples and interpolated to correct for drift. For addition information refer to Gingele and De Deckker [2005].

[18] $\mathrm{Sr}$ and $\mathrm{Nd}$ isotopes were measured by thermal ionization mass spectrometry using a ThermoFinnigan Triton TI multicollector mass spectrometer in static mode at RSES. Sr was run on single $\mathrm{Ta}$ filaments after loading in $\mathrm{H}_{3} \mathrm{PO}_{4}$. Nd was run on $\mathrm{Ta}$ (evaporation)- $\mathrm{Re}$ (ionization) double filaments after loading in $\mathrm{HNO}_{3}$ and dilute $\mathrm{H}_{3} \mathrm{PO}_{4}$. Reference values for ${ }^{87} \mathrm{Sr} /{ }^{86} \mathrm{Sr}$ and ${ }^{143} \mathrm{Nd} /{ }^{144} \mathrm{Nd}$ measured on the Triton mass spectrometer during this study are $0.710224 \pm 0.000011(2 \mathrm{SD}, \mathrm{n}=6)$ for the NIST SRM-987 Sr standard, and $0.512135 \pm 0.000010$ $(2 \mathrm{SD}, \mathrm{n}=4)$ for the Ames $\mathrm{nNd}-1$ standard, respectively. Additional information on procedures and errors is available in the work of Gingele and De Deckker [2005].

\subsection{Satellite Imagery of the October 2002 Dust Event}

[19] To detect and map the presence of the plume over the Australian continent, it was decided that a normalized difference (D) dust-enhancing algorithm developed by Miller [2003] for the Moderate Resolution Imaging Spectroradiometer (MODIS) sensor should be used. Furthermore, a simple satellite imagery time series of the plume was created by combining day and nighttime thermal infrared imagery of the MODIS and Advanced Very High Resolution Spectrometer (AVHRR).

\subsubsection{Dust Enhancement Algorithm}

[20] The Miller algorithm was developed at the Naval Research Laboratory (NRL) in Monterey, California, for United States military desert operations. This algorithm is primarily based on the $11 \mu \mathrm{m}$ and $12 \mu \mathrm{m}$ Thermal Infrared (TIR) channels, namely 31 and 32 , at $1 \mathrm{~km}$ resolution and spectral bands 1, 3, 4, and 26 .

[21] Two variants were developed; one to enhance the presence of dust over water (Dwat) and one to enhance the presence of dust over land (Dland). Of the two variants, only the latter was investigated in the context of the goals of this particular study. As described by Miller [2003], Dland was developed using both reflectance $(\mathrm{R})$ and brightness temperature (T) channels of the MODIS sensor. For a full description of the Miller algorithm terms and parameterization values, refer to Miller [2003].

\subsubsection{Satellite Imagery Time Series}

[22] To create a high temporal resolution time series of the progress of the plume, AVHRR imagery was acquired to fill the gaps between MODIS overpasses. Both the 1-km High Resolution Picture Transmission (HRPT) or Local Area Coverage (LAC) and $5 \mathrm{~km}$ Global Area Coverage (GAC) imagery formats were acquired to increase time series coverage of the plume to approximately 12 day and night scenes in a $24-\mathrm{h}$ period.

[23] As solar reflective channels in both sensors are not operational at night, it was decided that the visual time series would be created using thermal infrared bands (operational during both daytime and nighttime hours) common to both sensors. The imagery was therefore processed to derive the brightness temperature difference (BTD, seen as L1 term in Miller algorithm) between the $11 \mu \mathrm{m}$ and $12 \mu \mathrm{m}$ channels present in both sensors (bands 31 and 32 in MODIS, 5 and 6 in AVHRR). The depressed brightness temperature difference produced by dust in the imagery is vulnerable to water clouds with the same radiometric temperature if the coloration properties of dust in daytime solar reflective channels are not used. This limitation will be kept in mind when referring to the results of the visual time series.

\subsubsection{Image Processing: MODIS}

[24] The dust-enhancement stage of the satellite imagery analysis was carried out by applying the Miller algorithm to the MODIS scenes. The daynighttime series was then created from the BTD of the $11 \mu \mathrm{m}$ and $12 \mu \mathrm{m}$ channels in both sensors. To simplify the visualization of the BTD-derived time series, the resultant images were scaled as for L1 in the Miller algorithm, whereby the $[-2,2]$ scaling was retained, but contrary to processing for daytime Miller Dland, where normalization between $[0,1]$ is required, the scenes for this study were displayed on a blue-red color class scale matching the $[-2,2]$ histogram stretch.

\subsection{Trajectory Analysis and Meteorology}

[25] The NOAA Hybrid Single-Particle Lagrangian Integrated Trajectory (HYSPLIT) transport and dispersion model available on the Web at http:// www.arl.noaa.gov/ready/hysplit4.html was used to develop trajectories for the air mass that was associated with the dust plume, part of which 

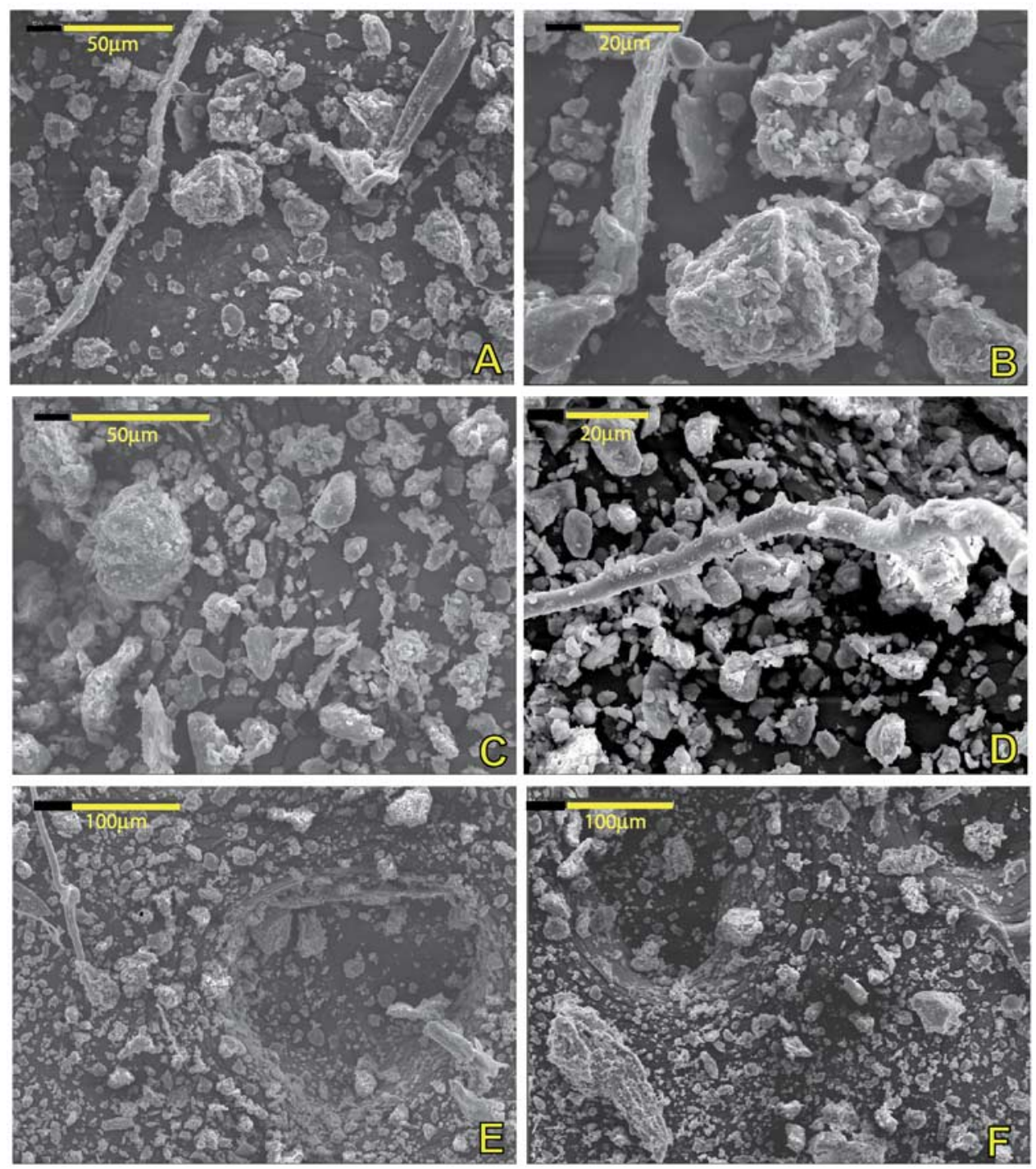

Figure 2. Selection of scanning electron microphotographs of some of the particles that made the dust that fell over Canberra during the night of 22-23 October 2002. The gray background consists of the double-sided sticky tape. Note the presence of $(a, b, d$, and e) long $(>200 \mu \mathrm{m})$ fibers and other organic remains (Figures 2a and 2e) and (f) charcoal. Note that Figure $2 b$ is an enlargement of Figure $2 a$ to show the agglomeration of small particles on larger ones. Figure 2e confirms the bimodality of the particles discussed in section 4.2.

traveled over Canberra. The model uses the final run (FNL) archive of the National Centers for Environmental Prediction (NCEP) Global Data Assimilation System (GDAS) model output. Other relevant meteorological data were also derived from the FNL archived data set.

\section{Results}

\subsection{Observation of Dust Particles and Other Material Under the SEM}

[26] A set of six scanning electron microphotographs showing the content of the dust that was entrained with the rain droplets during the night of 22-23 October 2003 are presented in Figure 2. The grains clearly vary in size, and several of them consist of agglomerates of much smaller particles, many of which are angular to subangular. Nevertheless, some large grains are also coated with smaller ones. Over $50 \%$ of the mineral grains consist of quartz, a very common mineral in arid/ desertic environments in Australia [Wasson, 1983; Pell and Chivas, 1995]. This is confirmed by the "light reddish brown" color of the sediment (5YR $5 / 6$ on the Munsell soil color chart), again a characteristic of much of the Australian interior [Wasson, 1983]. Up to $200 \mu \mathrm{m}$ long organic fibers 
Table 1. List of Lipid Compounds Identified in the Canberra Dust Sample

\begin{tabular}{|c|c|c|}
\hline & Lipid Compound & $\begin{array}{l}\quad \delta^{13} \mathrm{C} \text { Value } \\
\text { (Versus VPDB, } \\
\text { Corrected for TMS) }\end{array}$ \\
\hline 1 & unknown & \\
\hline 2 & Phthalate & \\
\hline 3 & $n-\mathrm{C}_{12: 0}$ alkanoic acid & -29.1 \\
\hline 4 & $n-\mathrm{C}_{14: 0}$ alkanoic acid & -28.6 \\
\hline 5 & Phthalate & \\
\hline 6 & $n-\mathrm{C}_{15: 0}$ alkanoic acid & -27.1 \\
\hline 7 & Phthalate & \\
\hline 8 & Methyl-PAH $(\mathrm{M}=242)$ & -27.1 \\
\hline 9 & $n-\mathrm{C}_{16: 1}$ alkanoic acid & \\
\hline 10 & $n-\mathrm{C}_{16: 0}$ alkanoic acid & -27.0 \\
\hline 11 & $n-\mathrm{C}_{18: 0}$ alkanol & -28.8 \\
\hline 12 & $n-\mathrm{C}_{18: 1}$ alkanoic acid & -26.9 \\
\hline 13 & Retene & \\
\hline 14 & $n-\mathrm{C}_{18: 0}$ alkanoic acid & -25.6 \\
\hline 15 & $n-\mathrm{C}_{22: 1}$ nitrile & \\
\hline 16 & Phthalate & \\
\hline 17 & Dehydroabietic acid & -30.3 \\
\hline 18 & $n-\mathrm{C}_{18: 1}$ amide & -28.2 \\
\hline 19 & unknown & \\
\hline 20 & Cholesterol & -23.3 \\
\hline 21 & $\beta$-sitosterol & \\
\hline 22 & Triterpenoid & \\
\hline 23 & Triterpenoid & \\
\hline
\end{tabular}

(of obvious plant origin) are clearly visible in most photographs (Figures 2a, 2b, 2d, and 2e). Charcoal particles are also present (Figure 2f). Despite thorough search of the stubs under the SEM, no pollen grains could be seen despite their richness recognized in another subsample that was specifically treated for pollen extraction. Another attempt was made to identify minute (e.g., a few $\mu \mathrm{m}$ long) cellular particles typical of microbes, but none could be seen due to the large amount of material stuck to the stub.

\subsection{Organic Composition of the Dust Sample}

\subsubsection{GC-Amenable Compounds}

[27] All identified lipid compounds in the Canberra dust sample are listed in Table 1 and indicated in Figure 3. The most abundant identified compound in the GC-MS trace is a methyl-polyaromatic hydrocarbon (PAH) with molecular weight of 242 $d a$ and a $\delta^{13} \mathrm{C}$ value of $-27.1 \%$ VPDB. Shortchain $\mathrm{C}_{12}-\mathrm{C}_{18} n$-alkanoic acids are present in moderate amounts as saturated and mono-unsaturated homologues with even-carbon-number predominance. They range in $\delta^{13} \mathrm{C}$ values from -25.6 to $-29.1 \%$ VPDB and $n$ - $\mathrm{C}_{18}$-alkanol is present in small amounts, with a $\delta^{13} \mathrm{C}$ value of $-28.8 \%$ VPDB. Several N-bearing compounds have tentatively been identified, e.g., $n-\mathrm{C}_{22: 1}$ nitrile and $n$ $\mathrm{C}_{18: 1}$ amide. Retene and dihydroabietic acid $\left(\delta^{13} \mathrm{C}\right.$ $=-30.3 \%$ VPDB) are present in small amounts, as are cholesterol and $\beta$-sitosterol. Two tentatively identified triterpenoid compounds with unconstrained functional groups are present in trace amounts. Several phthalate compounds are present in the sample. No long-chain $\left(>\mathrm{C}_{20}\right) n$-alkanes, $n$ alkanols, and $n$-alkanoic acids were detected. Markers for contributions from fossil fuel and petroleum, such as extended hopanes, are absent. Also, water-soluble compounds, such as sugars, are not present in the investigated dust extract likely due to the employed extraction scheme.

\subsubsection{Intact Polar Membrane Lipids}

[28] Owing to their relatively short turnover time [cf. White et al., 1979], intact membrane lipids are considered to be representative of fresh biomass present in environmental samples [Sturt et al., 2004; Biddle et al., 2006; Lipp et al., 2008]. To date, no analysis of this compound class has been reported. The applied protocol [Sturt et al., 2004] is unselective and detects molecular signals from all three domains of life, Archaea, Bacteria, and Eukarya. The distribution of intact polar lipids registered in the Canberra dust is extremely simple (Figure 4) and consistent with predominant contribution of plant debris to the fresh biomass transported with the dust. The two main compounds are phosphatidylcholine (PC) and phosphatidylethanolamine (PE). Their combined concentration in the dust sample amounts to about $430 \mathrm{ppm}$. Monounsaturated $\mathrm{C}_{16}$ and $\mathrm{C}_{18}$ are the most abundant acyl

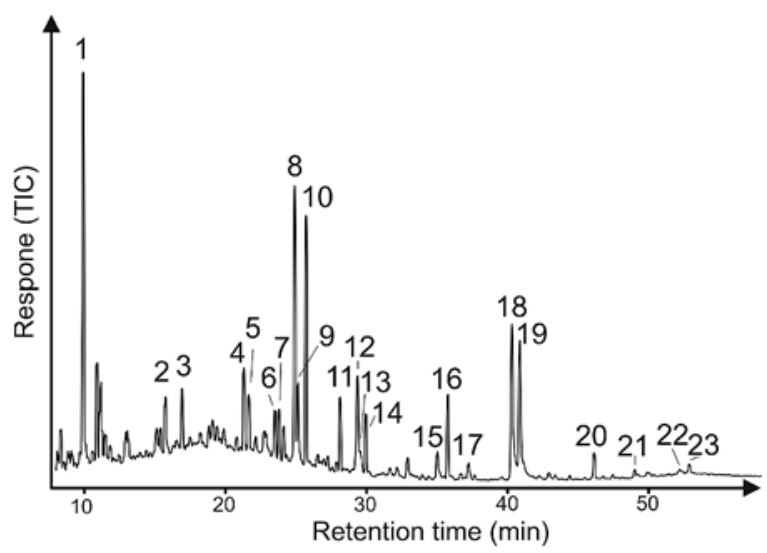

Figure 3. Total ion chromatogram of lipid compounds identified in the total lipid extract of Canberra dust, numbers refer to compounds listed in Table 1. 


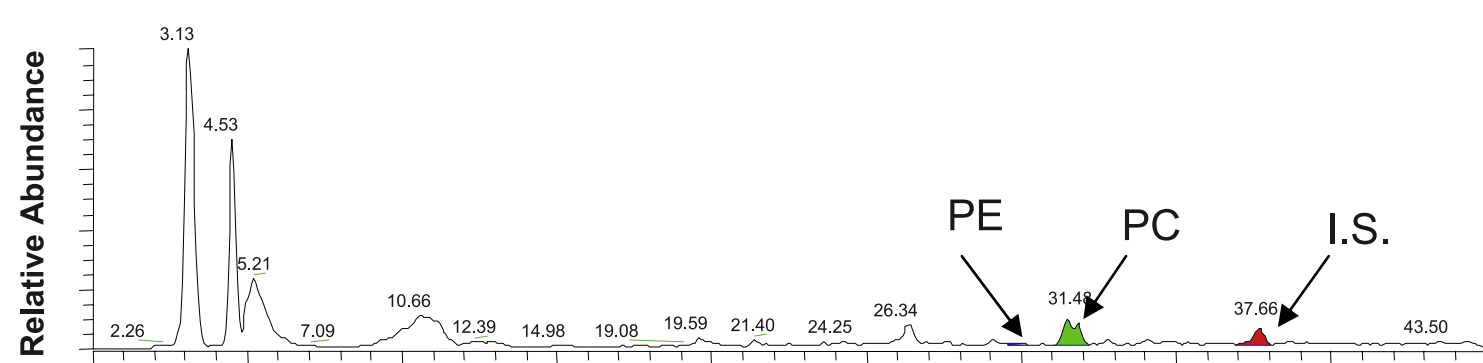

JL1376 RT: $003-4498$ Mass: $50000-200000$ NL: 2 23F9 F + c FSI Full ms [ $50000-200000]$

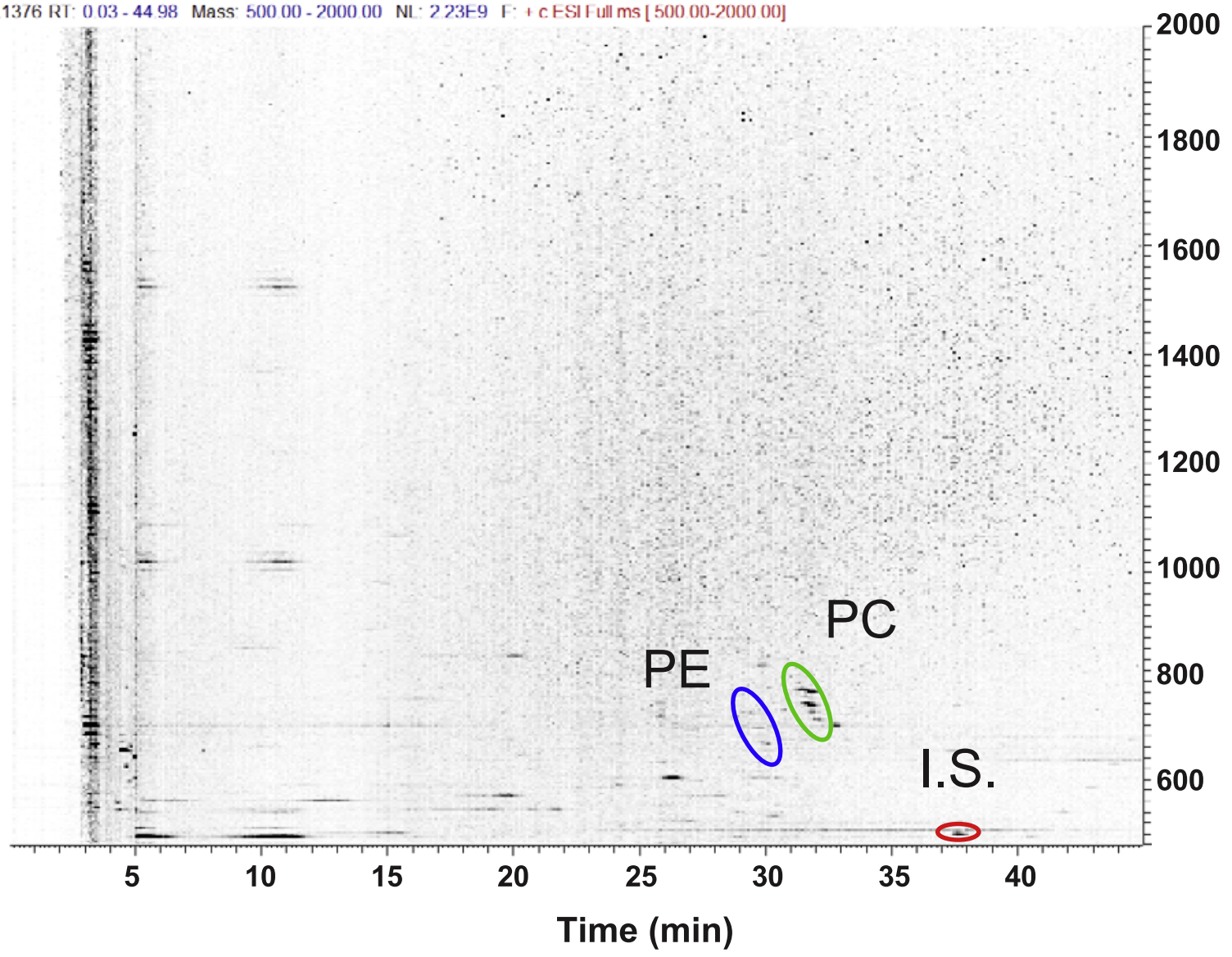

Figure 4. (top) Positive ion base-peak chromatograms and (bottom) density map from HPLC-MS analysis according to the protocol by Sturt et al. [2004] of intact polar membrane lipids in sample from Canberra dust event. Abbreviations: PE, phosphatidylethanolamine, PC, phosphatidylcholine, I.S., internal standard: 1-O-hexadecyl-2acetoyl-sn-glycero-3-phosphocholine.

moieties in both PE and PC, which is consistent with the distribution of free fatty acids (Figure 3, Table 1).

\subsection{Microbiology}

[29] DNA was successfully extracted and a total of 48 clones were sequenced and phylogenetically analyzed to obtain a measure of bacterial diversity. The calculated rarefaction curve showed that the clone library was far from saturation with a homologous coverage of ca. 19\%. The diversity seems to be high, as most of the randomly picked clones were different from each other. The obtained sequences were distributed among 39 operational taxonomic OTU units and belonged mainly to the groups Proteobacteria (12 clones), Bacteriodetes (11 clones), and Firmcutes (11 clones). The remaining fell into the groups Planctomycetes (5 clones), Acidobacteria (6 clones), and Cyanobacteria (1 clone). The single obtained cyanobacterial sequence is related to a cyanobacterium that has been associated with corals, some of which are healthy but also those that suffer from the blackband disease, as well as dead corals (see Shinn et al. [2000] and http://coastal.er.usgs.gov/african 


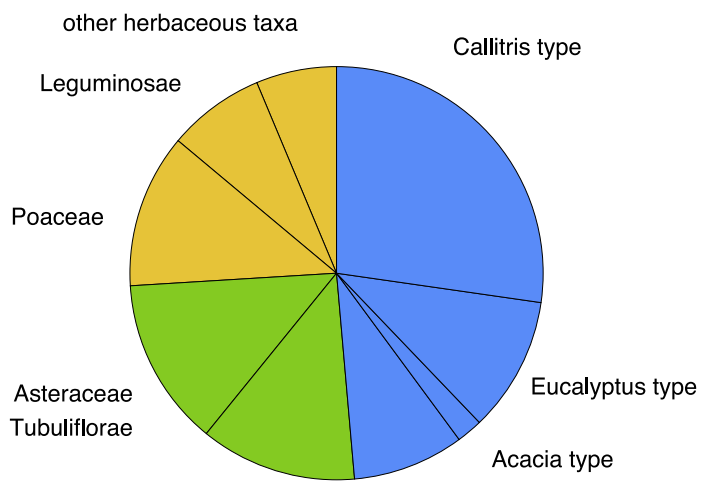

Amaranthaceae/Chenopodiaceae

other woody taxa

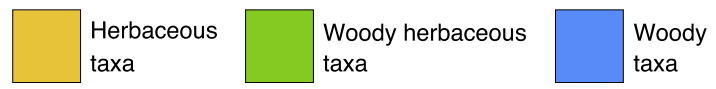

Figure 5. Pie diagram to show the percentage distribution of the pollen in the Canberra dust subsample. Note that the largest percentage relates to woody taxa with almost equal amounts of herbaceous taxa and woody herbaceous taxa.

dust/ for additional information). Many of the affiliates to cultured species originate from soils or desert crusts, usually first isolated at large distances from Australia.

\subsection{Pollen Content of the Dust Sample}

[30] The material extracted from the Canberra dust subsample was very rich in pollen (see Table $\mathrm{S} 1$ in the auxiliary material ${ }^{1}$ ); one transect under high magnification was enough to reach a high pollen sum. The dryland pollen spectrum is made up of an almost equal number of tree and shrub and herbaceous and woody herbaceous pollen. Tree and shrub pollen are dominated by Callitris and Eucalyptus-type pollen with a minor component of Acacia pollen, while Amaranthaceae/ Chenopodiaceae, Poaceae, Asteraceae, Tubuliflorae, and Leguminosae make up the bulk of the herbaceous and woody herbaceous pollen (see Figure 5). In addition, several aquatic taxa are present making up about $5.1 \%$ of the total pollen count. Also notable is the presence of fungal spores of the Sporormiella type; spores of this type are associated with ascomycete fungi found on the dung of herbivores and are common on the dung of large herbivores [Davis and Shafer, 2006]. Charcoal particles are abundant, with a

Auxiliary materials are available in the HTML. doi:10.1029/ 2008GC002091. value of 39.3 when expressed as percentage of the total pollen sum. Of interest also is the presence of Pinus pollen which is an introduced genus to Australia but which would not normally be associated with a pollen spectrum of this composition. It is noteworthy that in the Canberra region there were a substantial number of pine forests (Pinus radiate) which existed at the time of the dust event but which have almost all been destroyed by the devastating fires of January 2003. It is, therefore, of no surprise to find pine pollen as a producer of large amounts of pollen that can travel long distances due to its two globular sacs.

\subsection{Grain-Size Analysis}

[31] The grain-size analysis shows a relatively well sorted bimodal distribution with a dominant mode around $\sim 26 \mu \mathrm{m}$ and secondary mode around $\sim 150 \mu \mathrm{m}$. Classically, the grain-size distribution of a wind-blown deposit, resulting from dry deposition, is unimodal and very well sorted [e.g., Hesse and McTainsh, 1999; Krumbein and Pettijohn, 1938] although in some cases where significant amounts of platy minerals are present in the dust, a small coarse mode may occur [Stuut et al., 2005]. Previous analyses of Australian soils [e.g., Hesse, 2003; McTainsh and Duhaylungsod, 1989; Tate et al., 2007] and of deep marine sediments off Australia [Hesse and McTainsh, 1999] showed multimodal grain-size distributions. However, in the case of the soils these were most likely caused by the admixture of clays during pedogenesis, and in the case of marine sediments they should be interpreted as admixture of, e.g., river-derived sediments to the wind-blown fraction [Prins and Weltje, 1999; Stuut et al., 2002; Weltje and Prins, 2003]. In the case of the Canberra dust event, deposition of the dust resulted from both wet and dry deposition, which explains the fine tail of the distribution [Hesse and McTainsh, 1999]. In addition, this fine tail is an effect of the laser particle sizer, which tends to underestimate the clay fraction in natural samples due to the particle shape of clays [e.g., Konert and Vandenberghe, 1997].

[32] On the coarse end of the distribution, there is a small shoulder, which was also observed in an aeolian dust sample collected from the atmosphere over the Atlantic Ocean offshore Cameroon (Figure 3). This shoulder can be explained due to the shape of the mica minerals and other platy particles that are abundant in this sample (see Figure 6). Owing to the shape of these particles they show the similar aerodynamic behavior and will 


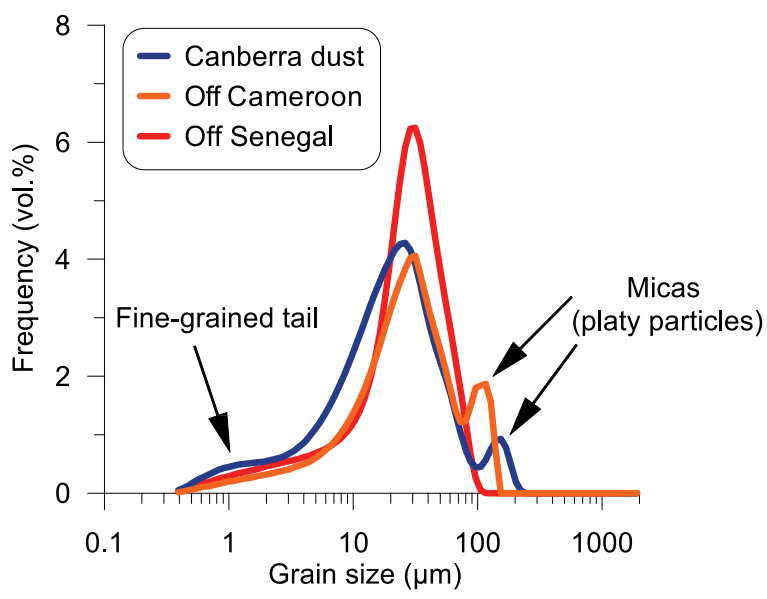

Figure 6. Grain-size distribution of the Canberra dust, compared with the distributions of dust collected from the atmosphere above the Atlantic Ocean offshore Cameroon [Stuut et al., 2005] and offshore Senegal (J.-B. Stuut, unpublished data, 2007).

have more or less the same settling velocities as smaller spherical particles like quartz and feldspar minerals. The laser particle sizer, however, describes these platy particles on an equivalentvolume basis, and therefore their "true size" is larger than their "aerodynamic size." If the grain-size analyses had been carried out using an estimation of the size based on settling of the particles (e.g., Sedigraph), this additional shoulder would most likely not have been observed.

\subsection{Major, Trace, and Rare Earth Elemental Composition of the Canberra Dust and $\mathrm{Sr}$ and Nd Isotopic Ratios}

\subsubsection{Background Information on the Murray Darling Basin}

[33] Gingele and De Deckker [2005] carried out an extensive geochemical sampling of the major rivers in the Murray Darling Basin (MDB) (Figure 7). These data sets have been used here to identify the possible source(s) of the airborne dust that "rained down" in Canberra in October 2002. The geochemical data for this Canberra dust are available in Table $\mathrm{S} 2$ in the auxiliary material.

\subsubsection{Comparison of All Elements and Some Isotopes From the Canberra Dust and Murray Darling Basin Fluvial Sediments}

[34] Principal component analysis was performed using the CANOCO 4.0 program (Canonical
Community ordination by correspondence analysis [see ter Braak, 1986; ter Braak and Smilauer, 1998]) to determine the close similarity of the Canberra dust against the fluvial samples from 32 sites in the MDB (sample GVC4 from the Onkaparinga River was excluded here). In total, 47 parameters were compared (major, traces, and rare earth as well as $\mathrm{Sr}$ and $\mathrm{Nd}$ isotopic ratios). Several sites plot in close vicinity as shown for the two principal axes (see Figure 8), and all appear to be originating from the Darling River in the driest part of the MDB.

\subsubsection{Some Elemental Ratios}

[35] Biplots used for comparing two elements from the MDB and Canberra dust data set were created with the aim of identifying similarities between the Canberra dust and some of the 32 sites from the MDB. Only a few elements would show some similarity between the Canberra dust and several of the sites in the MDB. Nevertheless, we attempted to compare elements such as $\mathrm{Ba}$ versus $\mathrm{K}$, $\mathrm{Hf}$ versus $\mathrm{Sr}$, Ti versus $\mathrm{Zr}$ and $\mathrm{Rb}$ versus $\mathrm{Cs}$, and none of the first three ratios, for example, showed any similarity between the Canberra Dust and any of the sites in the MDB. Only comparison of $\mathrm{Rb}$ and

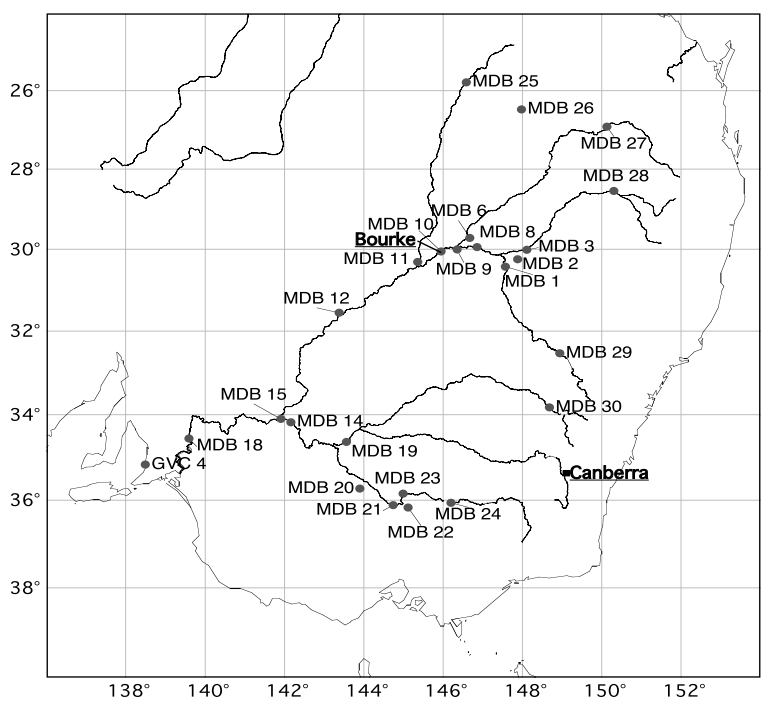

Figure 7. Map showing the major rivers in the Murray Darling Basin [MDB] and the location [red dots] of the fluvial samples studied by Gingele and De Deckker [2005] for which geochemical characteristics are compared against the Canberra dust that fell during the night of 22-23 October 2002. Note the presence of an additional sample taken from the Onkaparinga River south of Adelaide and that is located outside the MDB catchment. 


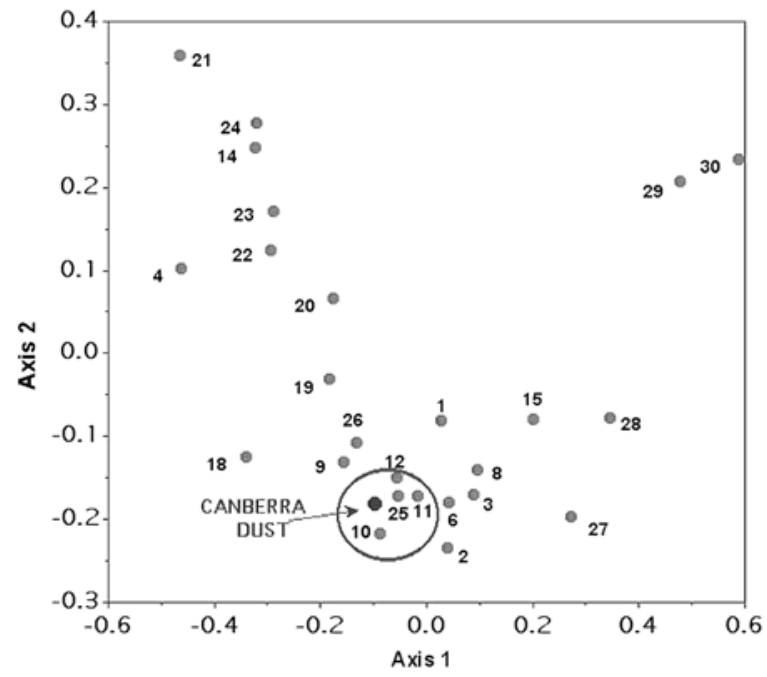

Figure 8. Diagram showing the close similarity of several samples (inside blue circle) from the Murray Darling Basin with the Canberra dust (blue dot) using the CANOCO 4.0 program (Canonical Community ordination by correspondence analysis). All elements (major, traces, and rare earth as well as $\mathrm{Sr}$ and $\mathrm{Nd}$ isotopes) were used for comparison between all samples. Numbers refer to the location of the fluvial samples located on the map in Figure 5 and should be preceded with the MDB prefix. The Onkaparinga sample has been omitted.

Cs shows some obvious coincidence (see Figure 9) with several sites in the Darling catchment.

\subsubsection{Insoluble Lanthanides}

[36] We have also attempted to normalize (by dividing the value for each element for any MDB site by the value for the corresponding element in the Canberra dust) all the elements for all the fluvial samples in the MBD and from the Onkaparinga River (GVC-4). The insoluble lanthanides (Pr, Sm, Gd, and Dy) demonstrated a level of closeness with the Canberra dust. It is no surprise that insoluble REEs are proving to be those that can be used for fingerprinting the origin of the Canberra dust. Those are presented in Figure 10. Three other elements ( $\mathrm{Y}, \mathrm{La}$, and $\mathrm{Ce}$ ) when normalized to Canberra dust also show closeness to the Canberra dust for site MD-9 in the MDB, but $\mathrm{Nd}$ did not (see below).

\subsubsection{Sr and Nd Isotopic Ratios}

[37] Gingele and De Deckker [2005] have already successfully used the isotopic ratios of $\mathrm{Sr}$ $\left({ }^{87} \mathrm{Sr} /{ }^{86} \mathrm{Sr}\right)$ and $\mathrm{Nd}\left({ }^{143} \mathrm{Nd} /{ }^{144} \mathrm{Nd}\right)$ to fingerprint the fluvial sediments in the Murray Darling Basin (same locations shown in Figure 1) and have also

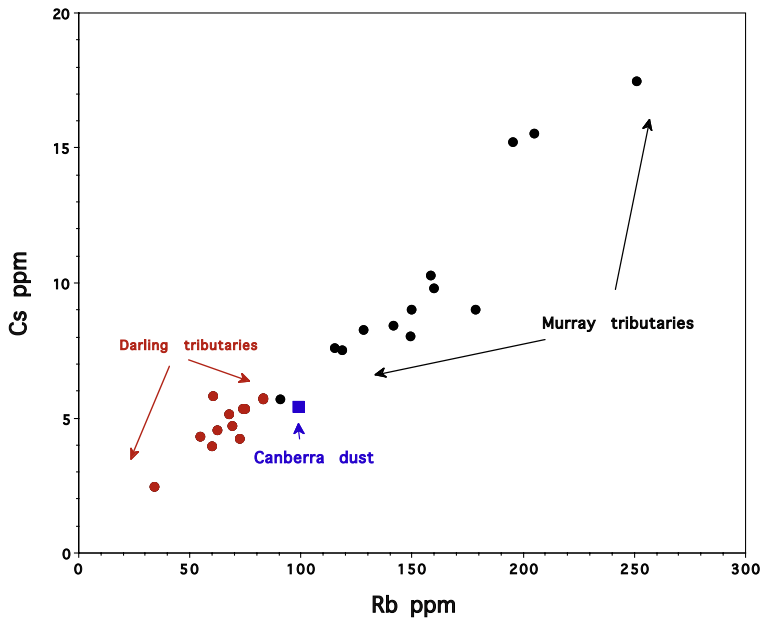

Figure 9. Elemental biplot to show that the $\mathrm{Rb}$ versus Cs can be used to identify the similarity of the Canberra dust sample with several fluvial sites along in the Darling catchment, including one from Macquarie River (MDB-1) with is closely located to several of the Darling tributaries. Note that all other sites in the Murray catchment plot far away from the Canberra dust values.

applied this method to identify the origin of riverine clays extracted in a deep-sea core located offshore the mouth of the River Murray [Gingele et al., 2007]. We have used the same approach with

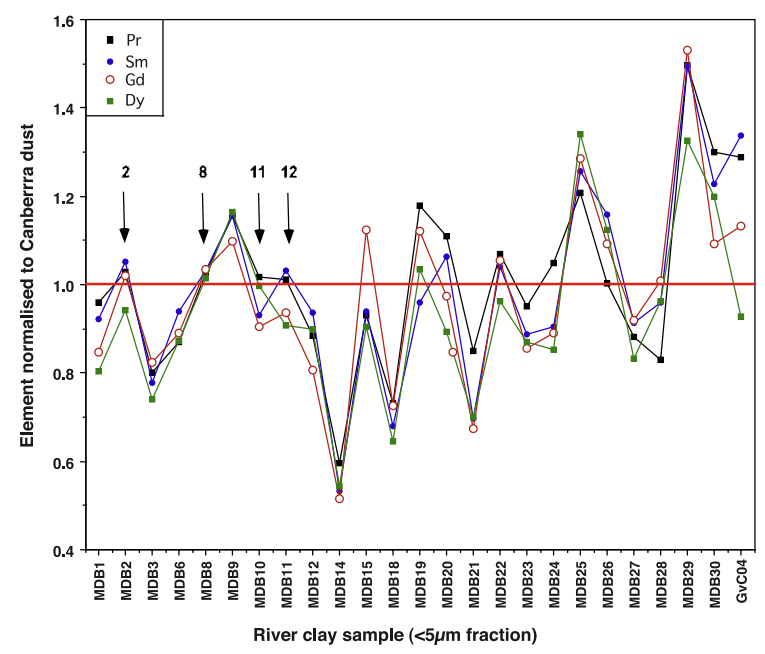

Figure 10. All the composition of the Murray Darling Basin and Onkaparinga River samples with respect to the insoluble Lanthanides rare earth elements (Pr, Sm, $\mathrm{Gd}$, and Dy) that have all been normalized against the Canberra dust. Numbers with a MDB prefix represent samples originating from different parts of the Basin. For relevant location, refer to Figure 7. Arrows indicate four locations (MDB 2, 8, 10, and 11) for which normalized values for the four REEs are very similar to those of the Canberra dust. 


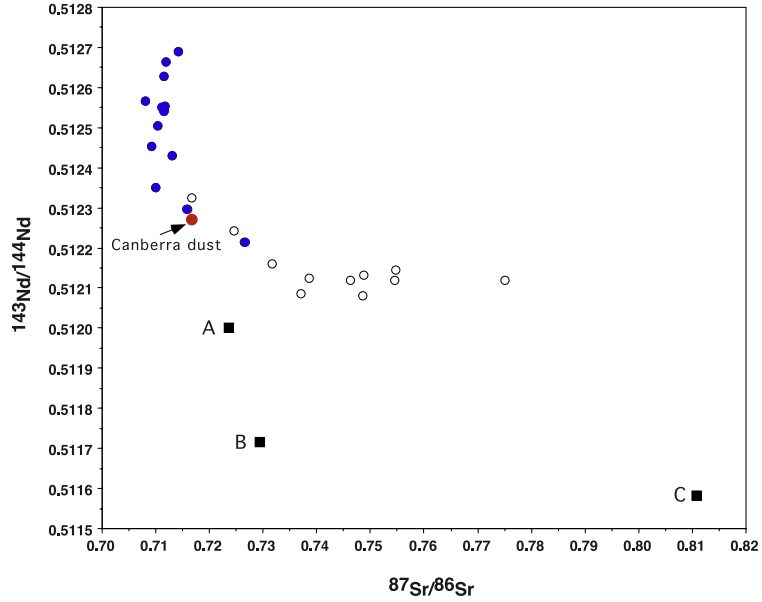

Figure 11. Plot of ${ }^{87} \mathrm{Sr} /{ }^{86} \mathrm{Sr}$ versus ${ }^{143} \mathrm{Nd} /{ }^{144} \mathrm{Nd}$ isotopic ratios for the Canberra dust compared with the values obtained by Gingele and De Deckker [2005] for fluvial samples from Darling River tributaries (blue circles) and River Murray tributaries (empty black circles). Three additional aeolian samples (samples AC) from Central and Western Australia are shown (for their respective locations, refer to Figure 1). Note that although the Macquarie River (blue dot with a $\mathrm{Nd}$ ratio close to 0.51222 ) is a tributary of the Darling, it drains through Lachlan Foldbelt lithologies. the analysis of the Canberra dust concerning the $\mathrm{Sr}$ and $\mathrm{Nd}$ isotopes and once again the plot shown in Figure 11 identifies that the samples plot close to the cluster of several of the tributaries of the Darling River. We also benefited from the analysis of 3 samples of aeolian dust collected from Central and Western Australia, in addition to other data presented by Revel-Rolland et al. [2006] and these are very distinct from the Canberra dust and other samples from the MDB. This is easily explained by the much older geologies for those three additional dust samples (samples A, B, and C; see Figure 1).

\subsection{Satellite Images}

\subsubsection{Dust Enhancement}

[38] Figure 12a shows the plume as it was presented by McTainsh et al. [2005] in a true-color SeaWiFS image at 0900 Eastern Standard Time (EST) on 23 October 2002. Scenes B and C (Figures 12b-12c) are color-optimized red-greenblue (B) and Miller-algorithm (C) variants of the same plume as seen by MODIS at 1325 EST. In both scenes, the plume is clearly differentiable
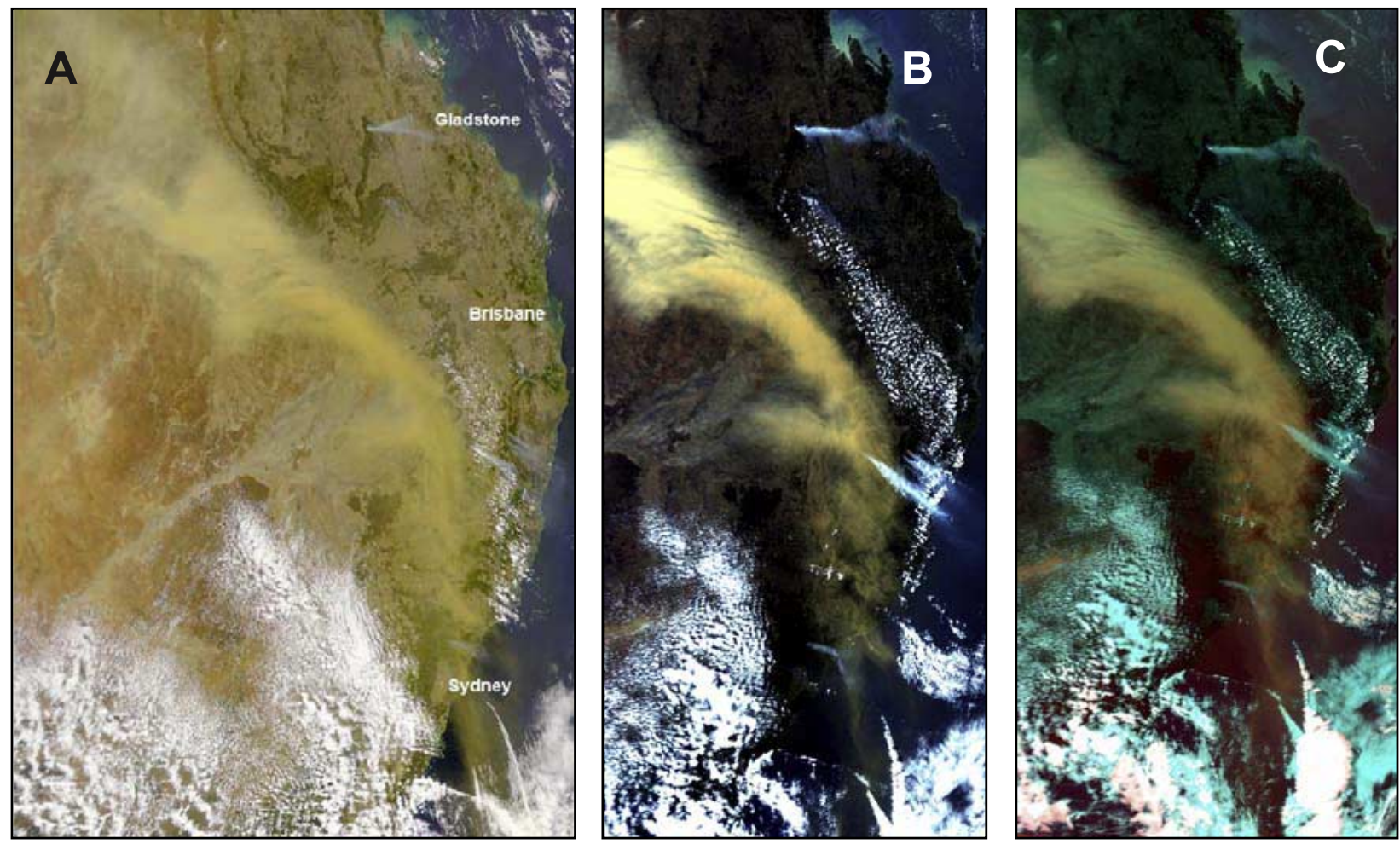

Figure 12. (a) SeaWiFS satellite image $0900 \mathrm{~h}$ local eastern standard time (EST) on 23 October 2002 (taken from McTainsh et al. [2005]), showing the main dust plume passing over eastern Australia (note the smoke plumes from bushfires in southeast Queensland and central east NSW, which indicate wind directions at the time of the event), (b) $1325 \mathrm{~h}$ EST-MODIS color-optimized red-green-blue image and (c) processed with the Miller Dust Enhancement Algorithm. 


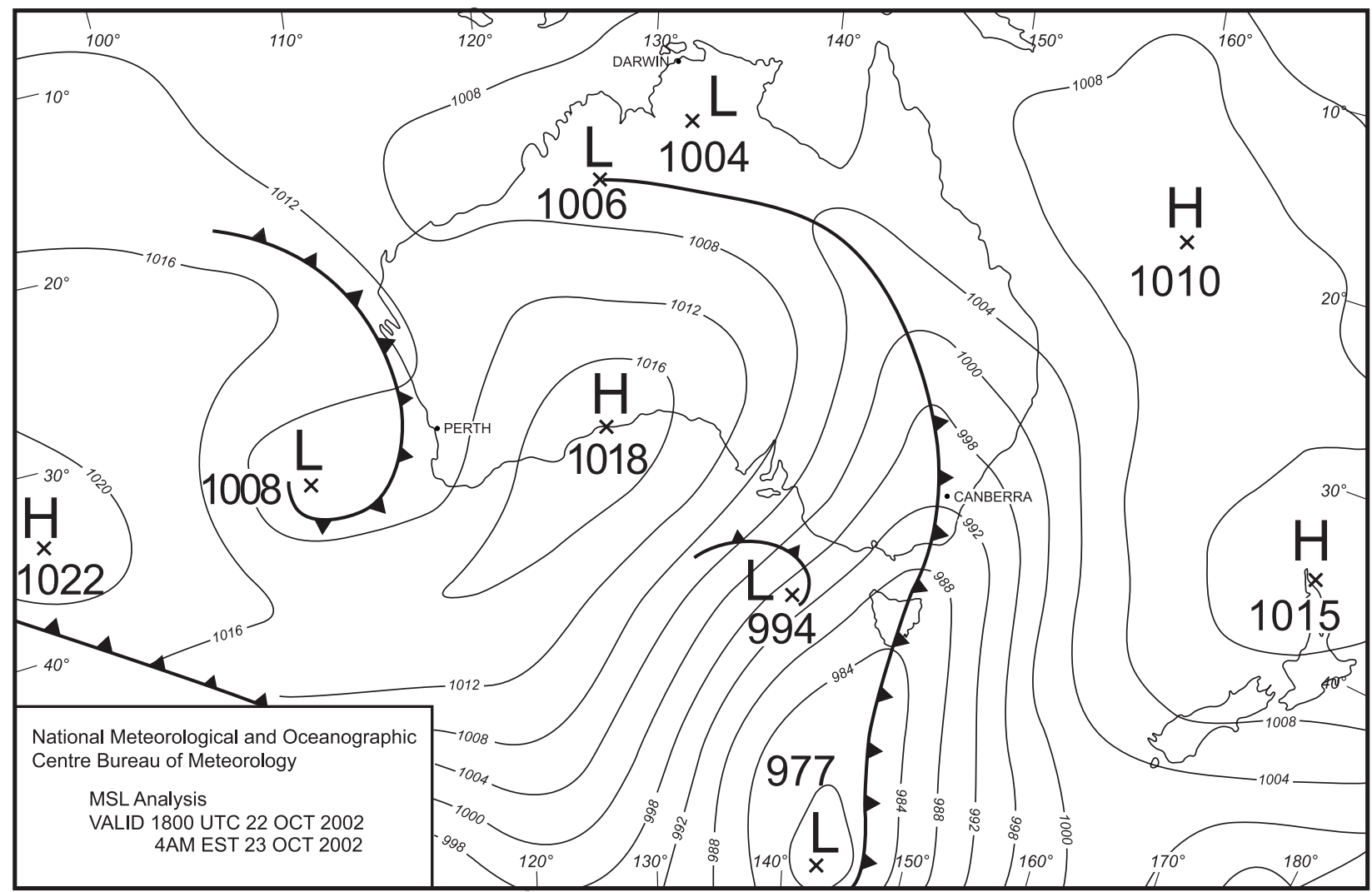

Figure 13. Synoptic chart showing the cold front-trough system passing through Canberra at 0400 EST on 23 October (1800 UTC, 22 October).

from the land, sea and cloud pixels. The smoke plumes referred to in the McTainsh et al. [2005] image (Scene A) are also clearly visible in the B and $\mathrm{C}$ scenes. Additional information on satellite images and processed data are provided as auxiliary material that includes two figures.

\subsection{Trajectory Analysis of the Plume That Brought Dust to Canberra on 22-23 October 2002}

[39] McTainsh et al. [2005] have shown previously that this dust storm was associated with a rapidly moving cold front and was approximately $2400 \mathrm{~km}$ long (aligned northwest-southeast along the frontal axis), $400 \mathrm{~km}$ wide, and constrained below 1.5$2.5 \mathrm{~km}$ above ground level (AGL) underneath a subsidence inversion. Figure 13 shows the cold front-trough system as it passed through Canberra at 0400 EST on 23 October.

[40] Figure 14 is a composite diagram showing the meteorological conditions associated with the dust transport to Canberra. Figure 14a shows forward atmospheric trajectories originating from the lower boundary layer (200 m AGL) at $31^{\circ} \mathrm{S}$ and $145^{\circ} \mathrm{E}$ (near the town of Bourke). The plots were produced at 12 hourly intervals from 0000 UTC (1000 EST) on 20 October using the NOAA HYSPLIT Transport and Dispersion Model (http:/www.arl. noaa.gov/ready/hysplit4.html). The trajectory plots show that early in the period transport from the Bourke region was generally toward the north under a relatively light southerly wind regime. The near-surface meteorology plots for Bourke (Figure 14b) show that this southerly flow continued until 1800 UTC on 21 October (0400 EST on 22 October). From 0000 UTC (1000 EST) on 22 October until the passage of the front at about 1800 UTC, northerly winds dominated. This northerly flow was associated with high temperatures and very low humidities. No rainfall was associated with the frontal passage through Bourke, assisting with dust entrainment. The trajectory plot for 0000 UTC (1000 EST) on 22 October (Figure 14a) shows clearly that air originating in the nearsurface layer at Bourke was advected directly over Canberra $\left(35.18^{\circ} \mathrm{S}, 148.11^{\circ} \mathrm{E}\right)$ at a height of close to $1000 \mathrm{~m}$ AGL some $18 \mathrm{~h}$ later. This equates to an average atmospheric transport speed of $\sim 40 \mathrm{~km} / \mathrm{h}$ over the $700 \mathrm{~km}$ distance. Precipitation 
$a$ Forward trajectories starting at 00 UTC 20 Oct. 2002 FNL Meteorological Data

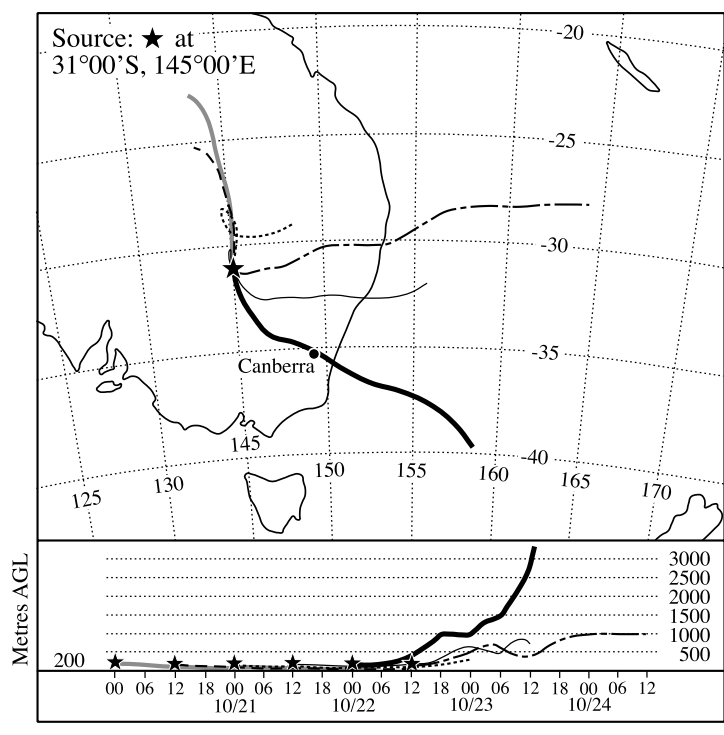

METEOGRAM

C Grid Point: 40.53 43.81 Lat. - 35.18 Lon.: 148.11 FNL Archive
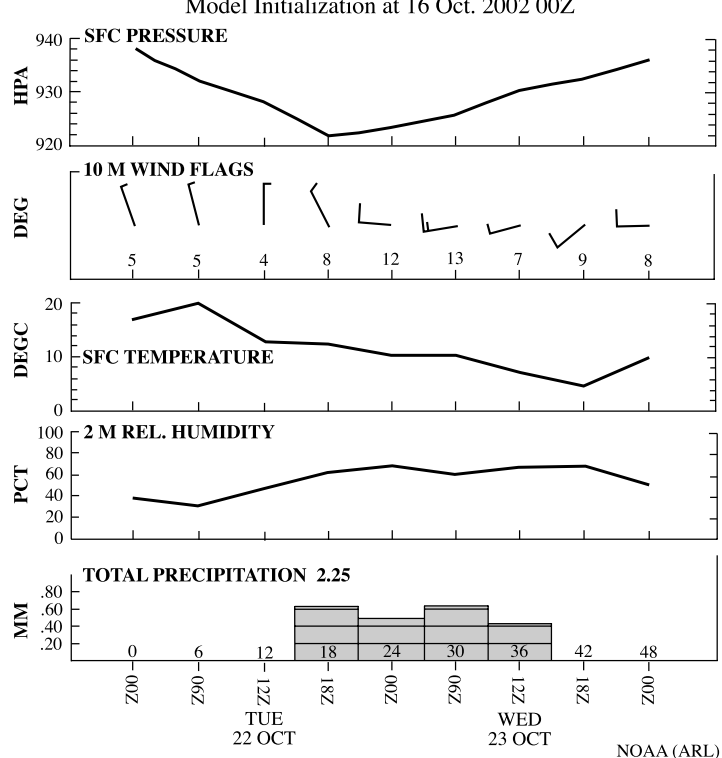

$b$ METEOGRAM Grid Point: 40.03 40.03 Lat. - 31.00 Lon.: 145.00 FNL Archive

Model Initialization at 16 Oct. $200200 Z$

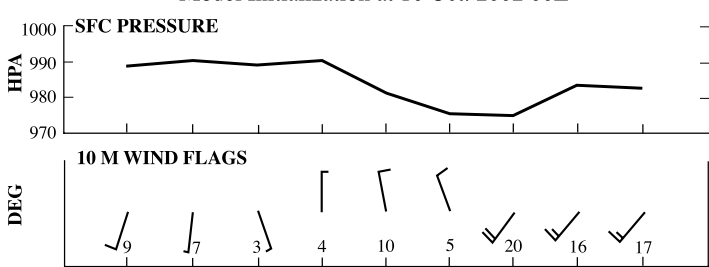

40 -SFC TEMPERATURE
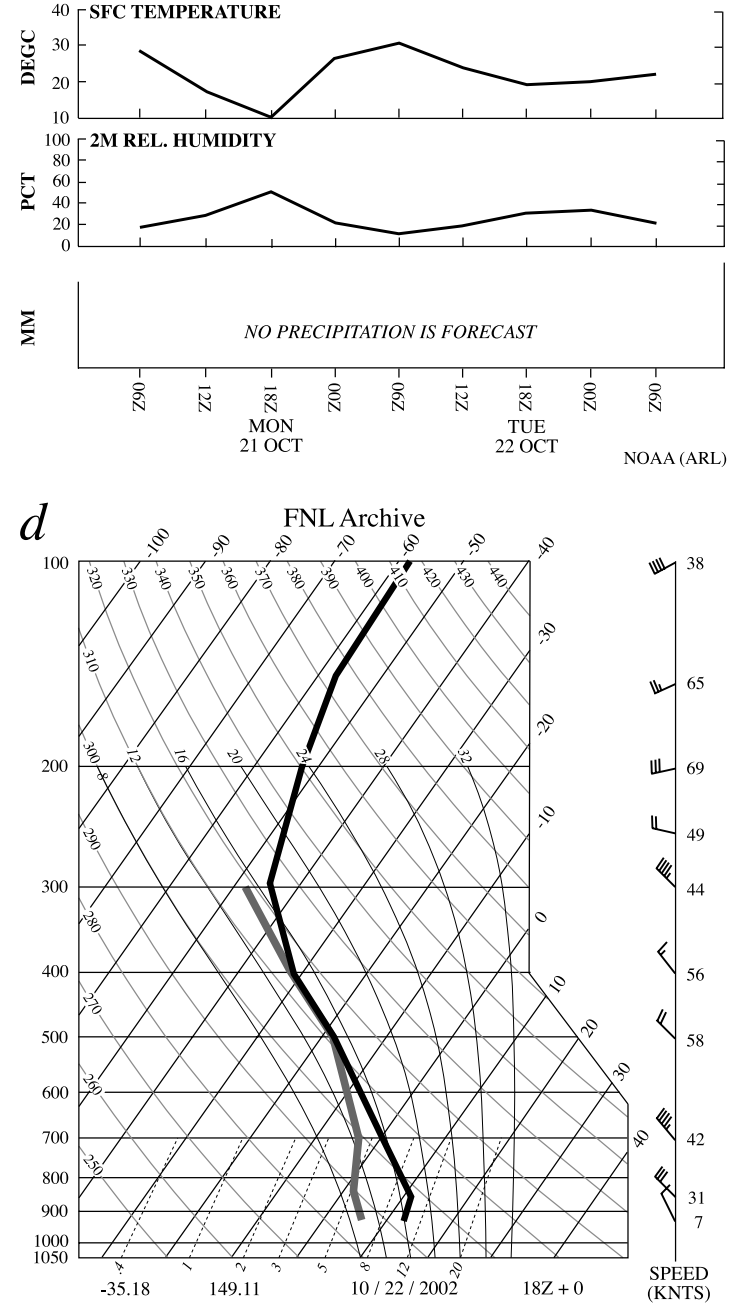

Figure 14. Composite diagram of the meteorological conditions associated with dust transport to Canberra, 22-23 October 2002. (a) Forward atmospheric trajectories originating at $200 \mathrm{~m}$ AGL above $31^{\circ} \mathrm{S}, 145^{\circ} \mathrm{E}(12$ hourly intervals from 0000 UTC on 20 October until 1200 UTC on 22 October). Trajectories are each of $48 \mathrm{~h}$ duration. (b) Meteorological data for $31^{\circ} \mathrm{S}, 145^{\circ} \mathrm{E}$ (near Bourke, New South Wales) for the period 0600 UTC 22 October until 0600 UTC 23 October. (c) Meteorological data for Canberra, Australian Capital Territory $\left(35.18^{\circ} \mathrm{S}, 148.11^{\circ} \mathrm{E}\right)$ for the period 0000 UTC 22 October until 0000 UTC 24 October. (d) Upper air sounding data for Canberra, 1800 UTC 22 October. See the text for details of data sources. 


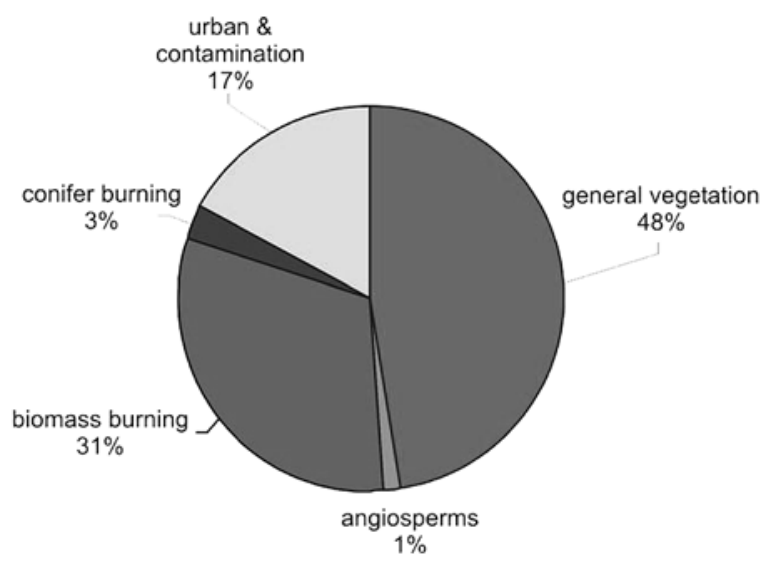

Figure 15. Source apportionment of GC-amenable lipid compounds of Canberra dust sample.

in Canberra associated with the pre-frontal cloud band that began at or before 1800 UTC (Figure 14c) produced the dust washout over Canberra. The archived upper air sounding for Canberra (Figure 14d) confirms that the cloud base was at about $550 \mathrm{hpa}(\sim 3500 \mathrm{~m} \mathrm{AGL})$ and that the atmosphere was saturated and precipitating above that level.

\section{Discussion}

\subsection{Sources of Organic Compounds in the Canberra Dust}

\subsubsection{GC-Amenable Compounds}

[41] The short-chain $\left(\mathrm{C}_{12}-\mathrm{C}_{18}\right) n$-alkanoic acids and alkanols are nonspecific biogenic markers forming basic units for all plant fats, oils, and lipids [Simoneit and Mazurek, 1982]. The high abundance of the $n$-alkenoic acids, e.g., $n$ - $\mathrm{C}_{16: 1}$ and $n-\mathrm{C}_{18: 1}$, points to a recent biosynthetic origin, as these compounds are rapidly oxidized in the atmosphere [Kawamura and Gagosian, 1987]. Their $\delta^{13} \mathrm{C}$ values indicate a predominant $\mathrm{C}_{3}$ plant origin. The absence of long-chain, i.e., $>\mathrm{C}_{20}, n$-alkanes, $n$-alkanols, and $n$-alkanoic acids in the sample imply a negligible contribution from plant waxes [Eglinton and Hamilton, 1967], which are normally found in high abundance in aerosols from grasslands or forest areas with leaf-bearing trees [Schefuß et al., 2003]. Most polyaromatic hydrocarbons (= PAHs) are common constituents of combustion emissions and are not source specific. The sole occurrence of the abundant alkyl PAH in this sample, however, points to biomass instead of fossil fuel burning. Alkyl PAHs were detected in relatively high concentrations in pine wood smoke
[Simoneit and Elias, 2000]. The absence of other fossil fuel markers, i.e., extended hopanes and steranes, supports this conclusion. The $\delta^{13} \mathrm{C}$ value of the alkylated PAH suggests a $C_{3}$ plant source. The occurrence of retene, proposed as an atmospheric tracer for conifer burning [Rahmdahl, 1983], further points to conifer wood as a source of the thermal combustion products. This suggestion is additionally supported by the occurrence of dehydroabietic acid, a molecular marker for softwood burning [Simoneit, 1999]. In that respect also the relatively high abundances of N-bearing compounds in the sample are of interest, as their occurrence in aerosols has been inferred to indicate burning of nitrogenous biomass [Bin Abas et al., 2004]. Also $\beta$ sitosterol, although present in all vegetation types and thus not source-specific, is often used as an indicator for direct emission from plants during biomass burning processes [Simoneit et al., 2004]. The two triterpenoids in the sample are likely degradation products of major triterpenoids found in angiosperms [Simoneit, 2002], whereas cholesterol either indicates an input from microbial sources or from cooking activity in urban areas [e.g., Rogge et al., 1991]. The abundant phthalates in the sample might indicate emissions from burning of urban refuse, as they are major constituents of plastics. We cannot, however, rule out a potential contamination from the sample container.

[42] On the basis of these inferences on lipid sources, the compounds have been summed up to a source apportionment based on quantifications of their total ion currents (TIC). These are: (1) general vegetation, (2) angiosperm vegetation, (3) biomass burning, subdivided into conifer fuel, where a distinction was possible, and (4) urban burning and cooking or contamination (Figure 15).

[43] The inference of biomass through the identification of specific compounds is of no surprise as examination of satellite images of the dust plume showed that it traveled through several smoke plumes, as at the time of the "dust event," SE Australia was affected by several bush fires.

[44] Compound 1 (Table 1; general vegetation in Figure 15) has a fragmentation pattern typical of resins from softwood and, therefore, would fall into the category of conifer-derived markers. The same applies to the absence of plant waxes indicative of leaf-bearing vegetation. Conifer needles do not contain many wax compounds. Callitris, being a gymnosperm, belongs to this category. In addition, markers for plant combustion such as retene and dihydroabietic acid (plus the unidentified resin 


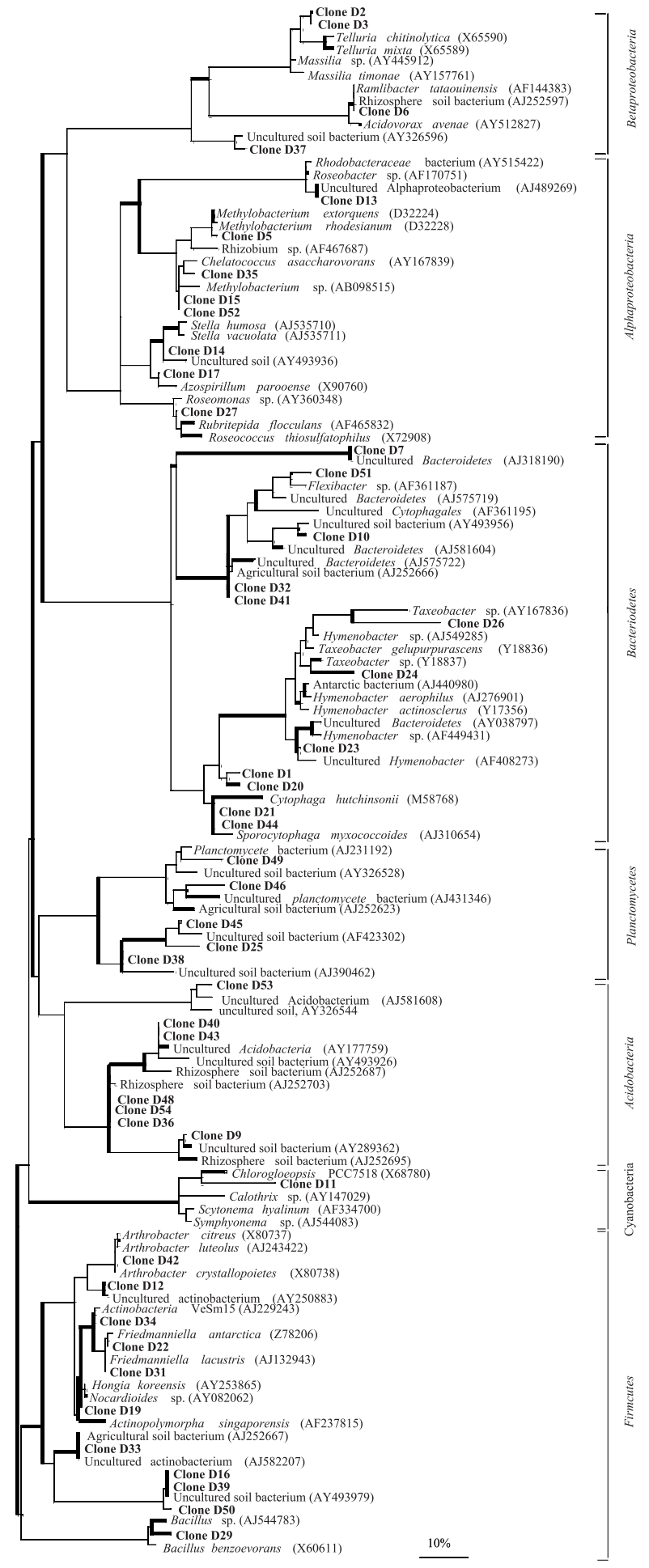

Figure 16. 16S rRNA-based phylogenetic reconstruction based on maximum-parsimony methods, showing the affiliation of sequences obtained from the Canberra dust sample. The dust clone sequences were inserted into the reconstructed consensus tree by applying parsimony criteria without allowing changes in the overall tree topology. The tree was simplified for clarity by omitting all sequences between clusters. The bar indicates $10 \%$ sequence divergence. product) point to the presence of gymnosperms. No lipid trace of cyanobacteria such as n-heptadecane or 2-methyl-hopanoids was detected.

[45] Compounds diagnostic of grass waxes play only a minor role in the extractable organic matter associated with the dust consistent with negligible input of grass-derived biomass. Surprisingly, pollen suggests a sizable contribution of particles originating from grasslands to the dust. This may indicate that (1) transport mechanism of grass pollen and wax compounds differ and/or (2) the wax signal in the extractable organic matter is rapidly overwhelmed by compounds from other sources, including plant combustion, anthropogenic processes, microbial matter sourced from desert crusts, and plant debris not associated with waxes.

\subsubsection{Intact Membrane Lipids}

[46] Notably, the concentration of intact membrane lipids is rather high (440 ppm), suggesting a significant contribution of fresh biomass to the dust. Although the two major lipids are known constituents in bacteria, the simplicity of the distribution and the high predominance of PC are consistent with a predominant origin of these membrane lipids from plants and fungi. PC is the major membrane lipid in eukaryotic cells and only present in a relatively small fraction of bacteria [cf. Sohlenkamp et al., 2003]. PE is widely distributed in all domains of life but its presence in the dust sample is probably reflective of fresh cellular debris from higher land plants in which it is a major compound type [Lerch and Stegemann, 1966]. Compounds typical for bacterial membrane constituents, e.g., phosphatidylglycerol or glycolipids, both commonly found in cyanobacteria [cf. Hölzl and Dörmann, 2007], are not detected under the analytical conditions applied. Intact membrane lipids of Archaea and Bacteria, possibly derived from soils and crusts, are likely to be present in the dust but presumably at concentration levels that are orders of magnitude lower than those of plant-derived analogs.

\subsection{Microbiology of the Canberra Dust}

[47] The obtained clones in our gene library contained almost full 16S rRNA genes, thus reflecting only living bacterial populations at the time of dust entrainment. Although we are aware that bacteria may have been killed while transported, they nevertheless remained detectable. A comparison with culture-based techniques, showed that the diversity in the dust sample has been strongly underestimated. The dust study of Griffin et al. [2001] reported five 
species in one dust event and 10 species in a second dust event (of which four were identical to the first samples). In a second study, Griffin et al. [2003] reported 19 bacterial isolates from various dust samples. In our DNA-based approach, the clones related to cultivable strains formed only a fraction of the total number of clones while the rest could not be related to known strains.

[48] The number of recovered clones does not represent the full diversity; the rarefaction curve indicated only $\sim 20 \%$ coverage. In spite of that, the Canberra dust appears rich in novel microorganisms because more than $50 \%$ of sequences had an $8-12 \%$ sequence divergence from their closest relative. The very high diversity can be attributed to the large area from which the dust originates including a wide diversity of habitats. It is, however, unlikely that the diversity reflects that of the original habitats. The transport process will have helped select microorganisms resistant to desiccation, oxygen, and radiation. Many of the obtained clones were related to clones from soil or soil crust origin (Figure 16). It is understandable, therefore, that microorganisms associated with soils and soil crusts are strongly represented in dust. In addition, a strongly represented group is the Actinobacter, which harbor a large number of spore-forming pathogens. Some of these originate from extreme environments (e.g., hypersaline, thermal, and arid Antarctic soils) [Stackebrandt and Schumann, 2006]. On the other hand, no known pathogens were identified and this is not surprising as they are rare in most environments. It is possible, nevertheless, that the rhizosphere associates (Figure 1 tree, e.g., clones D5, 6, 9, 36,48 , and 54) have pathogenic properties for plants [Coombs and Franco, 2003].

[49] Finally, from the clones with the least known relations, one is considered to be a cyanobacterium associated with Black Band disease in corals [Shinn et al., 2000] (http://coastal.er.usgs.gov/african_dust/). The less than $95 \%$ related clones are related to strains originally identified from North America, Asia, Africa, and Antarctica and therefore could be considered to be cosmopolitan in distribution. Nevertheless, owing to the limited number of clones and the absence of isolates, we could not find any potential pathogenic microorganisms in our dust sample.

\subsection{Source of the Canberra Dust Based on its Palynoflora}

[50] The potential pollen source area around Bourke and Cobar in western New South Wales (see Figure 1) is envisaged as it contains the following main vegetation types: Open Eucalyptus woodland with a lower stratum of Acacia and Callitris; open mixed Eucalyptus and Callitris woodland with grasses; open low Acacia woodland with a mixed lower stratum and smaller areas of open mixed Eucalyptus and Callitris forest and of Eucalyptus shrubland with a mixed lower stratum. The presence of Pinus pollen is really significant and is considered to point to some additional pollen being taken by the dust when it was over the Canberra region where extensive pine forests occurred until recently. (Note that Pinus is a prolific pollen producer and its pollen can travel long distances).

\subsection{Grain Sizes Recovered From the Canberra Dust}

[51] The dominant particle size mode of the Canberra dust sample compares very well with similar dust studies carried out on proximal dust collected relatively close to the source area on land [e.g., McTainsh et al., 1997]. The dust particles that were deposited during the Canberra dust event resulted not only from dry deposition but also from wet deposition by raindroplets that formed just above the dust as shown by the bi-modality in the grain size measurements.

\subsection{Source of the Canberra Dust Based on its Inorganic Composition}

[52] Gingele and De Deckker [2005] carried out a geochemical survey of the Murray Darling Basin, but with only 32 sampling stations for an area covering some $1 \times 10^{6} \mathrm{~km}^{2}$. Nevertheless, the concept these authors used was that fluvial clays, if suitably chosen, can represent an "overview" of the clays that will have originated within the catchment of a river. We consider that there may be some additional (recycled) aeolian component in rivers, but this amount today is minimal compared to what is being produced from the surrounding weathered lithologies. The River Murray and the Darling River drain very different lithologies of different ages (for further details, refer to Gingele and De Deckker [2005]). These differences are noticeable with a selection of particular elements and ratios of some of them. For example, the insoluble lanthanides, the ratio of $\mathrm{Cs}$ to $\mathrm{Rb}$ and $\mathrm{Sr}$ and $\mathrm{Nd}$ isotopic ratios, all clearly point to a source in the vicinity of Bourke to Cobar in western NSW in the proximity of the Darling River and some of its tributaries (see Figure 1). This is 
further confirmed by pooling all the elements (major, trace, and rare earths) together with the isotopic ratios of $\mathrm{Sr}$ and $\mathrm{Nd}$, in conducting a correspondence analysis of all the data against the Canberra dust, and this further confirms the location of the dust source, in this particular case, close to Bourke (see Figure 8).

\subsection{Meteorological Conditions Associated With the Dust Event}

[53] The multiproxy evidence of an origin near Bourke, New South Wales, for the dust deposited on Canberra overnight on 22-23 October, is unequivocally supported by the available meteorological and satellite remote sensing data. The cold front of 22-23 October was relatively intense and was associated with a parent low pressure system well to the south of the continent and a trough extending well into the tropics (Figure 13). Such intense, fast-moving, and geographically extensive front-trough systems are characteristic of the Australian continent in spring, when strong thermal contrasts across the landmass support intense frontogenesis well away from parent depressions in the Southern Ocean [Sturman and Tapper, 2005]. Many of the continent's most intense dust storms are associated with such features [McTainsh et al., 2005].

[54] It is worth noting here that while the frontal progression and apparent movement of the body of the plume is toward the northeast (refer to Figure 12), air motion ahead of and (at higher levels in the atmosphere) just behind the front is at right angles to the movement of the front (see Sturman and Tapper [2005] for a detailed explanation of frontal structure in the Australian region). It is this motion that is moving dust in this instance toward the southeast, from the northwest of New South Wales toward Canberra.

\section{Conclusions}

[55] We have successfully "fingerprinted" the dust that fell over Canberra overnight in October 2002. The dust's main provenance is along the semiarid lands surrounding the Darling River, most likely in the vicinity of Bourke and Cobar. This is supported by a combination of trace element and REEs analyses and also $\mathrm{Sr}$ and $\mathrm{Nd}$ isotopes when compared with the database obtained by Gingele and De Deckker [2005] for the Murray Darling Basin. The dust we studied here did not come from outside the Murray Darling Basin. The dust also consisted of a large spectrum of organic compounds, some of which confirm the nature of the vegetation such as is found along the Darling River. Evidence for biomass burning, mostly of softwood, is also detected and could have been taken by the dust plume on its journey to eastern Australia when it traveled though smoke produced by bush fires that proliferated in October 2002 as a result of long-lasting drought conditions. Contamination of the dust plume while in transit before falling over Canberra is further shown by the presence of Pinus pollen, an exotic taxon that is absent or extremely rare in the semiarid interior of Australia. This indicates that the dust plume collected additional "material" apart from at its source, and this is confirmed by the occurrence of plasticizer compounds and lipids ascribed to urban burning processes which point on a rapid overprint of aerosol lipid signatures in the urban sampling environment.

[56] The most surprising finding was the vast array of microbiobial taxa recognized in the sample. Many of the clones relate to organisms that have been recognized in arid regions such as in the western interior of North America and also from as far away as Antarctica. Our findings do not imply that such arid locations are the provenance of the taxa found in the dust that originated along the Darling River but that extreme environments on the planet do share many biological characteristics.

[57] Extensive examination and processing of MODIS satellite images demonstrate that the dust plume increased its load during its trajectory toward the Tasman Sea with some of the dust traveling as far as New Zealand and also delivering vast amount of dust to the Great Barrier Reef. This is particularly significant in light with the findings of Shinn et al. [2000], Griffin et al. [2001], and Garrison et al. [2003] that microbes and fungi transported in dust plumes that originated in Africa do play a role in the demise of coral reefs in the Caribbean.

[58] We will now apply many of the techniques listed in this study to fingerprint as many sites as possible in Australia that are potential sources of airborne dust. This is basic survey-type work, but it is not a trivial task. Australia is a vast continent, with diverse geologies, climatic conditions, and associated vegetations. To know the composition of its regolith and the microbiota it nurtures and the organic imprints it leaves in this country of contrasting conditions will help us better determine the impact of airborne dust on the health of our 
environment and eventually the oceans surrounding Australia where some of the dust eventually falls.

[59] The following step is to try to determine Australian dust fingerprints in oceanic and lacustrine cores in the Australian region but also as far afield as New Zealand, Antarctica, and South America.

\section{Acknowledgments}

[60] We acknowledge funding from the Australian Research Council Discovery grant DP 0772180 . PDD acknowledges the help of Judith Shelley for her outstanding help with bibliographical searches and for commenting on an early draft of the manuscript. John Rogers is also thanked for preparing the PCA data and diagram and Julius Lipp is thanked for the intact lipid analysis. We are also very grateful for the thorough reviews provided by an anonymous reviewer and Dale Griffin. Additional comments and recommendations by Theme guest editor M. Prins and chief editor V. Salters helped improve the paper.

\section{References}

Abed, R. M. M., and F. Garcia-Pichel (2001), Long-term compositional changes after transplant in a microbial mat cyanobacterial community revealed using a polyphasic approach, Environ. Microbiol., 3, 53-62.

Atlas, R. M., and R. Bartha (1998), Microbial Ecology. Fundamentals and Applications, 4th ed., Benjamin Cummins, Redwood City, Calif.

Biddle, J. F., et al. (2006), Heterotrophic Archaea dominate sedimentary subsurface ecosystems off Peru, Proc. Natl. Acad. Sci. U. S. A., 103, 3846-3851, doi:10.1073/pnas.0600035103.

Bin Abas, M. R., N. A. Rahman, N. Y. M. J. Omar, M. J. Maah, A. Abu Samah, D. R. Oros, A. Otto, and B. R. T. Simoneit (2004), Organic composition of aerosol particulate matter during a haze episode in Kuala Lumpur, Malaysia, Atmos. Environ., 38, 4223-4241, doi:10.1016/j.atmosenv.2004.01.048.

Chan, Y.-C., G. McTainsh, J. Leys, H. McGowan, and K. Tews (2005), Influence of the 23 October 2002 dust storm on the air quality of four Australian cities, Water Air Soil Pollut., 164, 329-348, doi:10.1007/s11270-005-4009-0.

Coombs, J. T., and C. M. M. Franco (2003), Isolation and identification of actinobacteria from surface-sterilized wheat roots, Appl. Environ. Microbiol., 69(9), 5603-5608, doi:10.1128/AEM.69.9.5603-5608.2003.

Davis, O. K., and D. S. Shafer (2006), Sporormiella fungal spores, a palynological means of detecting herbivore density, Palaeogeogr. Palaeoclimatol. Palaeoecol., 237, 40-50, doi:10.1016/j.palaeo.2005.11.028.

De Deckker, P. (1988), Biological and sedimentary facies of Australian salt lakes, Palaeogeogr. Palaeoclimatol. Palaeoecol., 62, 237-270, doi:10.1016/0031-0182(88)90056-9.

Duce, R. A., C. K. Unni, B. J. Ray, J. M. Prospero, and J. T. Merrill (1980), Long-range atmospheric transport of soil dust from Asia to North Pacific - Temporal variability, Science, 209, 1522-1524, doi:10.1126/science.209.4464.1522.

Eglinton, G., and R. J. Hamilton (1967), Leaf epicuticular waxes, Science, 156, 1322-1335, doi:10.1126/ science.156.3780.1322.
Garrison, V. H., E. A. Shinn, W. T. Foreman, D. W. Griffin, C. W. Holmes, C. A. Kellogg, M. S. Majewski, L. L. Richardson, K. B. Ritchie, and G. W. Smith (2003), African and Asian dust: From desert soils to coral reefs, BioScience, 53, 469-480, doi:10.1641/0006-3568(2003)053[0469:AAADFD]2.0.CO;2.

Gingele, F. X., and P. De Deckker (2005), Clay mineral, geochemical and Sr-Nd-isotopic fingerprinting of sediments in the Murray-Darling fluvial system, SE Australia, Aust. J. Earth Sci., 52, 965-974, doi:10.1080/08120090500302301.

Gingele, F. X., P. De Deckker, and M. Norman (2007), Late Pleistocene and Holocene climate of SE Australia reconstructed from dust and river loads deposited offshore the River Murray Mouth, Earth Planet. Sci. Lett., 255, 257272, doi:10.1016/j.epsl.2006.12.019.

Good, J. (1953), The population frequencies of species and the estimation of population parameters, Biometrika, 40, $237-264$

Griffin, D. W. (2007), Atmospheric movement of microorganisms in clouds of desert dust and implications for human health, Clin. Microbiol. Rev., 20(3), 459-477, doi:10.1128/ CMR.00039-06.

Griffin, D. W., V. H. Garrison, C. A. Kellogg, and E. A. Shinn (2001), African desert dust in the Caribbean atmosphere: Microbiology and public health, Aerobiologia, 17, $203-$ 213, doi:10.1023/A:1011868218901.

Griffin, D. W., C. A. Kellogg, V. H. Garrison, J. T. Lisle, T. C. Borden, and E. A. Shinn (2003), Atmospheric microbiology in the northern Caribbean during African dust events, Aerobiologia, 19, 143-157, doi:10.1023/B:AERO.0000006530. $32845.8 \mathrm{~d}$

Hesse, P. P. (1994), The record of continental dust dorm Australia in Tasman Sea sediments, Quat. Sci. Rev., 13, $257-$ 272, doi:10.1016/0277-3791(94)90029-9.

Hesse, P. P. (2003), Age of loess deposits in the Central Tablelands of New South Wales, Aust. J. Soil Res., 41, 11151131, doi:10.1071/SR02152.

Hesse, P. P., and G. McTainsh (1999), Last Glacial Maximum to early Holocene wind strength in the mid-latitudes of the Southern Hemisphere from aeolian dust in the Tasman Sea, Quat. Res., 52, 343-349, doi:10.1006/qres.1999.2084.

Hesse, P. P., and G. H. McTainsh (2003), Australian dust deposits: Modern processes and the Quaternary record, Quat. Sci. Rev., 22, 2007-2035.

Holmes, C. W., and R. Miller (2004), Atmospherically transported metals and deposition in the southeastern United States: Local or transoceanic?, Appl. Geochem., 19, 11891200, doi:10.1016/j.apgeochem.2004.01.015.

Hölzl, G., and P. Dörmann (2007), Structure and function of glycoglycerolipids in plants and bacteria, Prog. Lipid Res., 46, 225-243, doi:10.1016/j.plipres.2007.05.001.

Kawamura, K., and R. B. Gagosian (1987), Implications of $\omega$ oxocarboxylic acids in the remote marine atmosphere for photo-oxidation of unsaturated fatty acids, Nature, 325, 330-332, doi:10.1038/325330a0.

Konert, M., and J. Vandenberghe (1997), Comparison of laser grain size analysis with pipette and sieve analysis: A solution for the underestimation of the clay fraction, Sedimentology, 44, 523-535, doi:10.1046/j.1365-3091.1997.d01-38.x.

Krumbein, W. C., and F. J. Pettijohn (1938), Manual of Sedimentary Petrography, 1st ed., 549 pp., Appleton-CenturyCrofts, New York.

Landing, W. M., J. J. Perry, J. L. Guentzel, G. A. Gill, and C. D. Pollman (1995), Relationships between the atmospheric deposition of trace-elements, major ions, and mercury in Florida, Water Air Soil Pollut., 80, 343-352, doi:10.1007/ BF01189684. 
Lerch, B., and H. Stegemann (1966), Äthanolamin, ein verbreiteter Inhaltsstoff der Blätter höherer Pflanzen, Z. Naturforsch., 21B, 216-218.

Lipp, J. S., Y. Morono, F. Inagaki, and K.-U. Hinrichs (2008), Significant contribution of Archaea to extant biomass in marine subsurface sediments, Nature, 454, 991-994.

Ludwig, W., R. Amann, E. Martinez-Romero, W. Schonhuber, S. Bauer, A. Neef, and K. H. Schleifer (1998), rRNA based identification and detection systems for Rhizobia and other bacteria, Plant Soil, 204, 1-19, doi:10.1023/A:1004350708767.

Marx, S. K., B. S. Kamber, and H. A. McGowan (2005), Provenance of long-travelled dust determined with ultratrace element composition: A pilot study with samples from New Zealand glaciers, Earth Surf. Process. Landf., 30, 699716, doi:10.1002/esp.1169.

McTainsh, G. (1989), Quaternary aeolian processes and sediments in the Australian region, Quat. Sci. Rev., 8, 235-253, doi:10.1016/0277-3791(89)90039-5.

McTainsh, G., and N. C. Duhaylungsod (1989), Aspects of soil particle-size analysis in Australia, Aust. J. Soil Res., 27, 629-636, doi:10.1071/SR9890629.

McTainsh, G. H., W. G. Nickling, and A. W. Lynch (1997), Dust deposition and particle size in Mali, West Africa, $\mathrm{Ca}$ tena, 29, 307-322, doi:10.1016/S0341-8162(96)00075-6.

McTainsh, G., Y.-C. Chan, H. McGowan, J. Leys, and K. Tews (2005), The 23rd October 2002 dust storm in eastern Australia: Characteristics and meteorological conditions, Atmos. Environ., 39, 1227-1236, doi:10.1016/j.atmosenv. 2004.10.016.

Miller, S. D. (2003), A consolidated technique for enhancing desert dust storms with MODIS, Geophys. Res. Lett., 30(20), 2071, doi:10.1029/2003GL018279.

Muyzer, G., A. Teske, C. O. Wirsen, and H. W. Jannasch (1995), Phylogenetic relationships of Thiomicrospira species and their identification in deep sea hydrothermal vent samples by denaturating gradient gel electrophoresis of $16 \mathrm{~S}$ rDNA fragments, Arch. Microbiol., 164, 165-172, doi:10.1007/BF02529967.

Pell, S. D., and A. R. Chivas (1995), Surface features of sand grain microtextures from the Australian continental dunefield, Palaeogeogr. Palaeoclimatol. Palaeoecol., 113, 119132, doi:10.1016/0031-0182(95)00066-U.

Petherick, L., H. McGowan, and P. Moss (2008), Climate variability during the Last Glacial Maximum in eastern Australia: Evidence of two stadials?, J. Quaternary Sci., doi:10.1002/jqs.1186, in press.

Prins, M. A., and G. J. Weltje (1999), End-member modeling of siliciclastic grain-size distributions: The Late Quaternary record of eolian and fluvial sediment supply to the Arabian Sea and its paleoclimatic significance, SEPM Spec. Publ., 62, 91-111.

Prospero, J. M. (1999), Long-term measurements of the transport of African mineral dust to the southeastern United States US: Implications for air quality, J. Geophys. Res., 104, 15,917-15,927, doi:10.1029/1999JD900072.

Rahmdahl, T. (1983), Retene-A molecular marker of wood combustion in ambient air, Nature, 306, 580-582.

Revel-Rolland, M., P. De Deckker, B. Delmonte, P. P. Hesse, J. W. Magee, I. Basile-Doelsch, F. Grousset, and D. Bosch (2006), Eastern Australia: A possible source of dust in East Antarctica interglacial ice, Earth Planet. Sci. Lett., 249, $1-$ 13, doi:10.1016/j.epsl.2006.06.028.

Rogge, W. F., L. M. Hildemann, M. A. Mazurek, G. R. Cass, and B. R. T. Simoneit (1991), Sources of fine organic aerosol: 1.Charbroilers and meat cooking operations, Environ. Sci. Technol., 25, 1112-1125, doi:10.1021/es00018a015.
Savoie, D. L., and J. M. Prospero (1980), Water-soluble Potassium, Calcium and Magnesium \& $\mathrm{Mg}$ in the aerosols over the tropical Noprth-Atlantic, ... N. Atlantic, J. Geophys. Res., 85, 385-392, doi:10.1029/JC085iC01p00385.

Schefuß, E., V. Ratmeyer, J.-B. W. Stuut, J. H. F. Jansen, and J. S. Sinninghe Damsté (2003), Carbon isotope analyses of $n$ alkanes in dust from the lower atmosphere over the central eastern Atlantic, Geochim. Cosmochim. Acta, 67, 17571767, doi:10.1016/S0016-7037(02)01414-X

Shinn, E. A., G. W. Smith, J. W. Prospero, P. Betzer, M. L. Hayes, V. H. Garrison, and R. T. Barber (2000), African dust and the demise of the Caribbean coral reefs, Geophys. Res. Lett., 27, 3029-3032, doi:10.1029/2000GL011599.

Simoneit, B. R. T. (1999), A review of biomarker compounds as source indicators and tracers for air pollution, Environ. Sci. Pollut. Res., 6, 153-163.

Simoneit, B. R. T. (2002), Biomass burning - a review of organic tracers for smoke from incomplete combustion, Appl. Geochem., 17, 129-162, doi:10.1016/S08832927(01)00061-0.

Simoneit, B. R. T., and V. O. Elias (2000), Organic tracers from biomass burning in atmospheric particulate matter over the ocean, Mar. Chem., 69, 301-312, doi:10.1016/S03044203(00)00008-6.

Simoneit, B. R. T., and M. A. Mazurek (1982), Organic matter of the troposphere: II - natural background of biogenic lipid matter in aerosols over the rural western United States, Atmos. Environ., 16, 2139-2159, doi:10.1016/00046981(82)90284-0.

Simoneit, B. R. T., M. Kobayashi, M. Mochida, K. Kawamura, M. Lee, H. J. Lim, B. J. Turpin, and Y. Komazaki (2004), Composition and major sources of organic compounds of aerosol particulate matter sampled during the ACE-Asia campaign, J. Geophys. Res., 109, D19S10, doi:10.1029/ 2004JD004598.

Singleton, D. R., M. A. Furlong, S. L. Rathbun, and W. B. Whitman (2001), Quantitative comparisons of 16SrRNA gene sequence libraries from environmental samples, Appl. Environ. Microbiol., 67, 4374-4376, doi:10.1128/ AEM.67.9.4374-4376.2001.

Sohlenkamp, C., I. M. Lopez-Lara, and O. Geiger (2003), Biosynthesis of phosphatidylcholine in bacteria, Prog. Lipid Res., 42, 115-162, doi:10.1016/S0163-7827(02)00050-4.

Stackebrandt, E., and P. Schumann (2006), Introduction to the Taxonomy of Actinobacteria, The Prokaryotes, Springer, New York.

Sturman, A. P., and N. J. Tapper (2005), The Weather and Climate of Australia and New Zealand, 2nd ed., Oxford Univ. Press, Oxford, U. K.

Sturt, H. F., R. E. Summons, K. J. Smith, M. Elvert, and K.-U. Hinrichs (2004), Intact polar membrane lipids in prokaryotes and sediments deciphered by ESI-HPLC-MS ${ }^{\mathrm{n}}$ - new biomarkers for biogeochemistry and microbial ecology, Rapid Commun. Mass Spectrom., 18, 617-628, doi:10.1002/rcm.1378.

Stuut, J.-B. W., M. A. Prins, and J. H. F. Jansen (2002), A $300-$ kyr record of aridity and wind strength in southwestern Africa: Inferences from grain-size distributions of sediments on Walvis Ridge, SE Atlantic, Mar. Geol., 180, 221-233, doi:10.1016/S0025-3227(01)00215-8.

Stuut, J.-B. W., M. Zabel, V. Ratmeyer, P. Helmke, E. Schefuß, G. Lavik, and R. R. Schneider (2005), Provenance of present-day eolian dust collected off NW Africa, J. Geophys. Res., 110, D04202, doi:10.1029/2004JD005161.

Swap, R., M. Garstang, S. Greco, R. Talbot, and P. Kallberg (1992), Saharan dust in the Amazon basin, Tellus, Ser. B, 44, $133-149$. 
Talbot, R. W., M. O. Andreae, T. W. Andreae, and R. C. Harriss (1988), Regional aerosol chemistry of the Amazon during the dry season, J. Geophys. Res., 93, 1499-1508, doi:10.1029/JD093iD02p01499.

Tate, S. E., R. S. B. Greene, K. M. Scott, and K. G. McQueen (2007), Recognition and characterisation of the aeolian component in soils in the Girilambone Region, north western New South Wales, Australia, Catena, 69, 122-133, doi:10.1016/j.catena.2006.05.009.

ter Braak, C. J. F. (1986), Canonical correspondence analysis, a new eigenvector technique for multivariate direct gradient analysis, Ecology, 67, 1167-1179, doi:10.2307/1938672.

ter Braak, C. J. F., and P. Smilauer (1998), Canoco Reference Manual and Users Guide for Correspondant Analysis. Canonical Community Ordination (version 4), Microcomputer Power, New York.
Wasson, R. J. (1983), Dune sediment types, sand colour, sediment provenance and hydrology in the Strezelcki-Simpson dunefiled, Australia, in Aeolian Sediments and Processes, edited by M. E. Brookfield and T. S. Ahlbrandt, pp. 165195, Elsevier, Amsterdam.

Weltje, G. J., and M. A. Prins (2003), Muddled or mixed? Inferring palaeoclimate from size distributions of deep-sea clastics, Sediment. Geol., 162, 39-62, doi:10.1016/S00370738(03)00235-5.

White, D. C., R. J. Bobbie, J. D. King, J. S. Nickels, and P. Amoe (1979), Lipid analysis of sediments for microbial biomass and community structure, in Methodology for Biomass Determination and Microbial Activities in Sediments, edited by C. D. Lichtfeld and P. L. Seyfried, pp. 87-103, Am. Soc. for Test. and Mater., Philadelphia, Pa. 